\title{
Melastomataceae do Parque Estadual do Forno Grande, Espírito Santo, Brasil
}

\author{
Melastomataceae in the "Parque Estadual do Forno Grande", Espírito Santo, Brazil
}

Julia Meirelles ${ }^{1,3} \&$ Renato Goldenberg ${ }^{2}$

\begin{abstract}
Resumo
Apresenta-se o estudo taxonômico das espécies de Melastomataceae no Parque Estadual do Forno Grande, estado do Espírito Santo. Foram registradas 39 espécies, distribuídas em nove gêneros: Leandra (12), Miconia (12), Tibouchina (9), Bertolonia, Lavoisiera, Marcetia, Meriania, Microlepis e Pleiochiton (1 espécie cada). Quatro espécies representam novos registros para o estado: Bertolonia mosenii Cogn., Leandra aurea (Cham.) Cogn., L. tomentosa Cogn. e Tibouchina semidecandra Cogn. Três espécies encontram-se ameaçadas de extinção, segundo a Lista do Espírito Santo: Meriania tetramera Wurdack, Miconia octopetala Cogn. e Tibouchina castellensis Brade, endêmica do local. São apresentados chave de identificação, descrições, ilustrações e dados de distribuição geográfica das espécies.
\end{abstract}

Palavras-chave: Floresta Atlântica, florística, taxonomia.

\begin{abstract}
We present a taxonomic study on the Melastomataceae in the "Parque Estadual do Forno Grande", Espírito Santo state. There are 39 species distributed in nine genera: Leandra (12), Miconia (12), Tibouchina (9), Bertolonia, Lavoisiera, Marcetia, Meriania, Microlepis and Pleiochiton (1 species each). Four species represent new records for the state: Bertolonia mosenii Cogn., Leandra aurea (Cham.) Cogn., L. tomentosa Cogn. and Tibouchina semidecandra Cogn. Three species are threatened, according to the "Lista do Espírito Santo": Meriania tetramera Wurdack, Miconia octopetala Cogn. and Tibouchina castellensis Brade, a local endemic. We also present identification key, descriptions, illustrations and information on geographic distribution of the species. Key words: Atlantic Forest, floristic, taxonomy.
\end{abstract}

\section{Introdução}

Melastomataceae compreende cerca de 4.570 espécies distribuídas em 166 gêneros (Clausing $\&$ Renner 2001), em sua maioria tropical, com cerca de dois terços restritos à região Neotropical (Wurdack 1962). É uma das famílias mais importantes da flora brasileira com a ocorrência de 68 gêneros e aproximadamente 1312 espécies (Baumgratz et al. 2010a). Possuem hábito herbáceo, arbustivo, arbóreo ou mais raramente epifítico e lianescente (Martins 2009). A maioria dos seus representantes é prontamente reconhecida principalmente pelas folhas decussadas com nervação acródroma, estames frequentemente falciformes, conectivo desprovido de glândula dorsal e anteras poricidas (Renner 1993; Romero $\&$ Martins 2002). Melastomataceae constitui um grupo monofilético suportado pela venação acródroma e pelos dados moleculares combinados das regiões do cloroplasto $\mathrm{rbcL}$, ndhF e rpl16 (Clausing \& Renner 2001).

No estado do Espírito Santo são encontradas diversas formações vegetacionais como manguezais, restingas, Florestas de Tabuleiro, Floresta Ombrófila Densa de Terras Baixas, Submontana, Montana, Alto-montana, Estacional Semidecidual e Campos de Altitude (Simonelli \& Fraga 2007). A Floresta Atlântica do Espírito Santo é rica em endemismos (Backes \& Irgang 2004), especialmente a região serrana que, juntamente com o sul da Bahia, detém recorde de diversidade botânica no mundo (Thomaz et al. 1998). Também é extremamente diversa em Melastomataceae, com várias espécies e um gênero (Dolichoura Brade) endêmicos (Brade 1959; Goldenberg \& Reginato 2006; Goldenberg \& Tavares 2007). Simonelli \& Fraga (2007)

\footnotetext{
${ }^{1}$ Universidade Estadual de Campinas, Depto. Biologia Vegetal, Av. Bertrand Russel s/n, Cidade Universitária Zeferino Vaz, 13083-970, Campinas, SP, Brasil.

${ }^{2}$ Universidade Federal do Paraná, Depto. Botânica, Setor de Ciências Biológicas. C.P. 19031, 81531-970, Curitiba, PR, Brasil.

${ }^{3}$ Autor para correspondência: jmeirell@gmail.com
} 
posicionaram Melastomataceae como a sétima família mais importante em número de espécies no Espírito Santo, com 111 táxons, dos quais ca. de 35\% (39 espécies) ocorrem na área do Parque Estadual do Forno Grande (PEFG).

Este trabalho teve por objetivos conhecer a composição da família Melastomataceae no Parque Estadual do Forno Grande e prover dados para identificação das espécies encontradas, através da apresentação de chave de identificação, descrições, ilustrações e comentários taxonômicos, ecológicos e de distribuição geográfica.

\section{Material e Métodos}

O Parque Estadual do Forno Grande (PEFG) é uma Unidade de Conservação (UC) de Proteção Integral, situada no município de Castelo, ao sul do estado do Espírito Santo, nas coordenadas $20^{\circ} 31^{\prime} 13$ "S e $41^{\circ} 6$ '21"W. Esta UC ocupa área de aproximadamente 730 ha, com altitudes entre 1.000 e $2.080 \mathrm{~m}$, sendo a cota máxima representada pelo Pico do Forno Grande, o segundo ponto mais alto do estado (Ipema 2005). A região possui clima mesotérmico brando superúmido com estação subseca de apenas dois meses, entre julho e agosto. Ocorre o predomínio de temperaturas amenas durante o ano todo (a média anual varia em torno de $18^{\circ}$ a $20^{\circ} \mathrm{C}$ ) (IBGE 1977). A vegetação do Parque é constituída de Floresta Ombrófila Densa Montana e Alto-montana, em transição para a Floresta Estacional Semidecidual (Ipema 2005). São comuns os afloramentos rochosos entremeados pelas florestas de altitude. Nos afloramentos ocorre uma vegetação diferenciada, herbáceo-arbustiva com espécies das famílias Amaryllidaceae, Bromeliaceae, Cactaceae, Campanulaceae Gesneriaceae, Melastomataceae e Velloziaceae, além de diversos liquens e samambaias (J. Meirelles). A área é classificada como de extrema importância biológica, dentro das áreas prioritárias para a conservação da biodiversidade da Mata Atlântica (Conservation International do Brasil et al. 2000).

A área onde atualmente situa-se o PEFG foi uma das poucas do Espírito Santo visitadas por botânicos no passado, sendo localidade típica para diversas espécies da flora brasileira, sendo muitas endêmicas. Por possuir pontos de difícil acesso dentro da área do Parque, as localidades mais coletadas foram as mais acessíveis: trilha para as piscinas, Mirante, Balança e Pico do Forninho.
Os exemplares registrados foram depositados nos herbários CEPEC, MBML, RB, UPCB, e quando duplicatas estão depositadas em todos os quatro herbários, o material examinado está citado como UPCB* (acrônimos segundo Thiers 2010). A coleta e herborização dos ramos de indivíduos férteis foram realizadas ao longo das trilhas de acordo com as técnicas de Toledo (1942), totalizando seis excursões por parte dos autores, entre os meses de fevereiro de 2008 e novembro de 2010.

Além do material obtido nas coletas, foram consultadas as coleções de Melastomataceae provenientes do PEFG dos herbários MBML, RB e UPCB.

As descrições enfatizam as principais características diagnósticas das espécies de acordo com o grupo taxonômico. Algumas características não estão na descrição e sim nos comentários para a espécie. A coloração das pétalas foi determinada como mutável, ou não, segundo as observações em campo. O número de nervuras das folhas foi complementado pelo sinal de + e o número 2 quando há presença de um par submarginal tênue adicional (Goldenberg 2004). Todas as espécies cujos frutos continham mais de 20 sementes foram citadas como possuidoras de sementes numerosas. Material adicional de outras localidades do Espírito Santo ou de estados vizinhos foi analisado quando necessário. Os dados de distribuição geográfica das espécies para o Brasil seguiram Baumgratz et al. (2010a). Foram classificadas como arbustivas as plantas com fuste ramificado desde seu início. Não foram adotados táxons infraespecíficos.

\section{Resultados e Discussão}

Melastomataceae está representada no PEFG por 39 espécies distribuídas em nove gêneros: Leandra Raddi (12), Miconia Ruiz et Pav. (12), Tibouchina Aubl. (nove), Bertolonia Raddi, Lavoisiera DC., Marcetia DC., Meriania Sw., Microlepis (DC.) Miq. e Pleiochiton Naudin ex A.Gray (uma espécie cada). A maioria das espécies ocorre exclusivamente nas áreas de Floresta Ombrófila Densa Montana e Alto-montana, somando 22 espécies dos gêneros Bertolonia, Leandra, Meriania, Miconia, Pleiochiton e Tibouchina. Outras espécies ocorrem nas áreas expostas a insolação, em trilhas abertas ou bordas de matas como, por exemplo, Leandra aurea (Cham.) Cogn., L. foveolata (DC.) Cogn, M. oleifolia (DC.) Triana, T. cerastifolia (Naudin) Cogn. e T. heteromalla (Don) Cogn. Algumas espécies ocorrem exclusivamente 
nos afloramentos rochosos, como: Lavoisiera imbricata (Thumb.) DC., Leandra tomentosa Cogn., Marcetia taxifolia (A.St.-Hil.) DC., T. castellensis Brade e T. radula Markgr.

Dentre as espécies analisadas, quatro são novos registros para o Espírito Santo: B. mosenii Cogn., Leandra aurea (Cham.) Cogn., L. tomentosa Cogn. e T. semidecandra Cogn. Três espécies encontramse ameaçadas de extinção, segundo Simonelli \& Fraga (2007): Meriania tetramera Wurdack, Miconia octopetala Cogn. e T. castellensis Brade, endêmica do local. As Melastomataceae são bastante representativas na flora do PEFG e aparecem como a quarta maior família em número de espécies, ficando atrás apenas de Orchidaceae, Asteraceae e Bromeliaceae (Amorim et al. dados não publicados).
Muitas espécies de Melastomataceae coletadas no PEFG também ocorrem na Estação Biológica de Santa Lúcia, Santa Teresa (ES) onde Goldenberg \& Reginato (2006) registraram 56 espécies. Esta, talvez seja a área mais densamente coletada na região serrana do Espírito Santo. Outros trabalhos de floras de Melastomataceae realizados no Brasil demonstram a riqueza de espécies em áreas de florestas montanas e alto-montanas: Macaé de Cima no estado do Rio de Janeiro com 109 spp. (Baumgratz et al. 2010b), Serra das Lontras no sul da Bahia com 53 spp. (Jardim et al. 2009), e também em áreas de campos rupestres de Minas Gerais, como na Serra da Canastra com 91 espécies (Romero \& Martins 2002) e Serra do Cipó com 90 espécies (Semir et al. 1987).

\section{Chave para identificação para os gêneros e espécies de Melastomataceae no Parque Estadual do Forno Grande}

1. Plantas epífitas ou rupícolas de pequeno porte.

2. Ramos e face abaxial das folhas revestidos por glândulas; fruto cápsula triquetra

1. Bertolonia mosenii

2'. Ramos e face abaxial das folhas revestidas por tricomas simples, eglandulosos; fruto bacáceo ... 30. Pleiochiton blepharodes

1'. Plantas terrestres ou eventualmente rupícolas, neste caso de médio ou grande porte.

3. Folhas adultas menores que $1 \mathrm{~cm}$ compr.

4. Folha com base obtusa; pétalas rosadas a lilases

2. Lavoisiera imbricata

4'. Folha com base cordada; pétalas brancas 15. Marcetia taxifolia

3'. Folhas adultas maiores que $1 \mathrm{~cm}$ compr.

5. Fruto do tipo cápsula.

6. Folhas com nervuras suprabasais; frutos com sementes piramidais a piramidaisalongadas 16. Meriania tetramera

6'. Folhas com nervuras basais; frutos com sementes cocleadas.

7. Hipanto revestido por tricomas estrelados

29. Microlepis oleifolia

7'. Hipanto revestido por tricomas simples, dendríticos ou glandulares (Tibouchina).

8. Plantas herbáceas a subarbustivas; flores 4-(5) meras; cálice persistente no fruto 33. T. cerastiifolia

8'. Plantas arbustivas ou arbóreas; flores 5-(6) meras; cálice caduco.

9. Pétalas de coloração mutável de brancas a alvo-lilases; estames com conectivo densamente revestido por tricomas glandulares

31. T. arborea

9'. Pétalas de coloração lilás ou roxa não mutável; estames com conectivo glabro a moderadamente revestido por tricomas glandulares.

10. Hipanto urceolado; pétalas lilases 32. T. castellensis

10'. Hipanto oblongo ou campanulado; pétalas roxas.

11. Anteras exclusivamente brancas; estames menores com conectivo prolongado $0,3-0,5 \mathrm{~mm}$ abaixo das tecas

37. T. radula

11'. Anteras lilases, roxas ou apenas em um ciclo brancas ou beges; estames menores com conectivo prolongado $0,5-2,4 \mathrm{~mm}$ abaixo das tecas. 
12. Folhas com margem serreada; hipanto $10-15 \mathrm{~mm}$ compr.

38. T. semidecandra

12 '. Folhas com margem inteira; hipanto $3,8-8,5 \mathrm{~mm}$ compr.

13. Hipanto densamente revestido por tricomas glandulares

13'. Hipanto revestido por tricomas não glandulares.

14. Hipanto revestido por tricomas dendríticos; filetes revestidos por tricomas simples .... 34. T. estrellensis

14'. Hipanto revestido por tricomas simples; filetes revestidos por tricomas glandulares.

15. Ramos cilíndricos; flores solitárias ou em dicásio

35. T. fothergillae

15'. Ramos quadrangulares; flores em panículas

36. T. heteromalla

5'. Fruto do tipo baga.

16. Flores com pétalas de ápice arredondado ou retuso (Miconia).

17. Inflorescências terminais e laterais.

18. Ramos revestidos por tricomas estrelados, densos; anteras deiscentes por dois poros ventralmente inclinados semelhantes a rimas

22. M. latecrenata

18'. Ramos glabros; anteras deiscentes por poro apical único

28. M. tristis

17'. Inflorescências exclusivamente terminais.

19. Flores 8-meras

23. M. octopetala

19'. Flores 4-6 meras.

20. Anteras deiscentes através de poros ventralmente inclinados, semelhantes a rimas.

21. Folhas com nervuras basais; anteras abrindo-se da base até ao ápice das tecas 24. M. pusilliflora

21'. Folhas com nervuras suprabasais; anteras abrindo-se por $1 / 2$ a $2 / 3$ do comprimento das tecas

26. M. sellowiana

20'. Anteras deiscentes através de $1-4$ poros apicais.

22. Anteras deiscentes através de 4 poros apicais.

23. Folhas com superfície abaxial esparsamente recoberta por tricomas simples e estrelado-estipitados; hipanto urceolado 20. M. hirtella

23'. Folhas com superfície abaxial glabra; hipanto campanulado

27. M. theaezans

22'. Anteras deiscentes através de poro apical único.

24. Folhas com o tecido laminar aparente

18. M. doriana

24 '. Folhas com o tecido laminar recoberto pelo indumento.

25. Folhas com superfície abaxial revestida por tricomas lepidotos (achatados).

26. Folhas com nervuras 5+2; ovário revestido esparsamente por tricomas estrelados 19. M. formosa

26'. Folhas com nervuras 3+2; ovário glabro .... 17. M. chartacea

$25^{\prime}$. Folhas com superfície abaxial revestida por tricomas dendríticos ou estrelados.

27. Folhas com superfície abaxial revestida por tricomas dendríticos; lacínias externas em forma de dentículos

25. M. saldanhae

$27^{\prime}$. Folhas com superfície abaxial revestida por tricomas estrelados; lacínias externas triangulares

21. M. kriegeriana

16'. Flores com pétalas de ápice agudo ou acuminado a raramente apiculado (Leandra)

28. Arvoreta; folhas jovens com a presença de tricomas estrelado-estipitados e simples na superfície adaxial 14. Leandra sp. 2

28'. Arbustos; folhas com superfície adaxial glabra ou revestida por tricomas simples, dendríticos ou estrelados não estipitados.

29. Ramos, face adaxial das folhas e hipanto glabros

3. L. acutiflora

29'. Ramos, face adaxial das folhas e hipanto pilosos.

30. Inflorescências terminais e laterais

13. Leandra sp. 1

30'. Inflorescências exclusivamente terminais. 
31. Flores 6-meras

10. L. melastomoides

31'. Flores 5-meras.

32. Anteras amarelas in sicco.

33. Folhas com nervuras $3+2$; anteras $5-5,8 \mathrm{~mm}$ compr.

8. L. gardneriana

33'. Folhas com nervuras 5+2; anteras 2,6-3,1 mm compr.

11. L. nianga

32'. Anteras rosadas, brancas ou beges in sicco.

34. Folhas com nervuras basais.

35. Nervuras 3+2; panícula $3-8 \mathrm{~cm}$ compr.

4. L. aspera

$35^{\prime}$. Nervuras 5+2; panícula 9,5-16 cm compr.

5. L. aurea

34'. Folhas com nervuras suprabasais.

36. Anteras rosadas in sicco.

37. Ramos revestidos por tricomas simples

7. L. foveolata

37'. Ramos revestidos por tricomas dendríticos

6. L. carassana

36'. Anteras brancas ou beges in sicco e in vivo.

38. Hipanto 3,9-4,8 mm compr.; cálice persistente

38'. Hipanto 2-3,4 mm compr.; cálice caduco

9. L. longisetosa

12. L. tomentosa

1. Bertolonia mosenii Cogn., Fl. bras. 14(4): 55. 1886.

Fig. 1a-c

Epífita; ramos quadrangulares, mais velhos glabros, mais jovens com glândulas moderadas. Folhas com pecíolo 0,6-4,8 cm compr.; lâmina $2,5-8,7 \times 1,6-5 \mathrm{~cm}$, elíptica, base aguda a obtusa, margem levemente serreada, ápice cuneado, face adaxial esparsamente revestida por tricomas simples, prostrados, face abaxial moderadamente revestida por glândulas castanhas, nervuras $3+2$, basais. Cimeira 5-7,5 cm compr., terminal, flor não vista. Cápsula triquetra; cálice caduco; sementes numerosas, oval-alongadas.

Material examinado: Rio Manso, 15.X.2008, fr., C.N. Fraga et al. 2249 (MBML, RB, UPCB); 19.V.2010, fr., J. Meirelles et al. 449 (MBML, RB).

Bertolonia mosenii ocorre nos estados de MG, RJ, SP, PR, SC, ES (primeiro registro). No PEFG ocorre apenas em Floresta Ombrófila Densa Montana sobre rochas às margens de córrego, em local sombreado. Distingue-se pelo hábito epifítico e cápsula triquetra. Foi observada apenas uma população com poucos indivíduos.

\section{Lavoisiera imbricata DC., Prodr. 3: 103. 1828. \\ Fig. 1d-e}

Arbusto a arvoreta $1-1,8 \mathrm{~m}$ alt.; ramos sub-cilíndricos a quadrangulares, glabros. Folhas sésseis imbricadas; lâmina 5-8,6 × 2,5-4,6 mm, oval, base obtusa, margem serreado-ciliada, ápice agudo e apiculado, ambas as faces glabras, nervuras 3 , basais. Flores solitárias terminais, 6-meras; hipanto 3,8-4,2 $\mathrm{mm}$ compr., campanulado, glabro; cálice simples, caduco; lacínias lineares- lanceoladas; pétalas rosadas a lilases, obovadooblongas, ápice obtuso; estames 12, dimórficos, conectivo prolongado $2,2-3 \mathrm{~mm}$ abaixo das tecas, apêndices ventrais, linear-oblongos, anteras 2,3-2,7 mm compr., amarelas, ovais a oblongas, ápice acuminado-arredondado, poro apical único; ovário $2 / 3$ ínfero, glabro, 6-locular, estilete 4,4-5,7 mm compr., reto, glabro. Cápsula deiscente da base em direção ao ápice; sementes numerosas, oblongas a encurvadas.

Material examinado: 10.VII.2004, fl., L. Kollmann \& R.L. Kollmann 6847 (MBML, UPCB); afloramento por baixo do Mirante, Inselberg, 16.VII.2008, fl., A.P. Fontana et al. 5377 (MBML, UPCB); 9.IV.2009, fl. e fr., J. Meirelles et al. 296 (CEPEC, MBML, UPCB); 22.V.2010, fl., J. Meirelles et al. 489 (UPCB*).

Lavoisiera imbricata está distribuída nos estados de BA, GO, DF, MG, ES, SP, RJ, PR. No PEFG é restrita aos afloramentos rochosos expostos ao sol, inseridos em Floresta Ombrófila Densa Montana, onde é relativamente comum. Distingue-se pelas folhas menores que $1 \mathrm{~cm}$ compr., imbricadas e sésseis, ramos decorticantes folhosos no ápice e desnudos na base e pelas cápsulas que se rompem da base para o ápice.

3. Leandra acutiflora (Naudin) Cogn., Fl. bras. 14(4): 162. 1886.

Fig. $1 \mathrm{f}-\mathrm{g}$

Arbusto ca. $2 \mathrm{~m}$ alt.; ramos cilíndricos, aplanados próximo as inflorescências, glabros. Folhas com pecíolo 0,-5 cm compr.; lâmina 4,4-12 $\times 1,3-5,2 \mathrm{~cm}$, lanceolada, elíptico-lanceolada a obovada, base atenuada à aguda, margem inteira, ápice acuminado, face adaxial glabra, face abaxial 

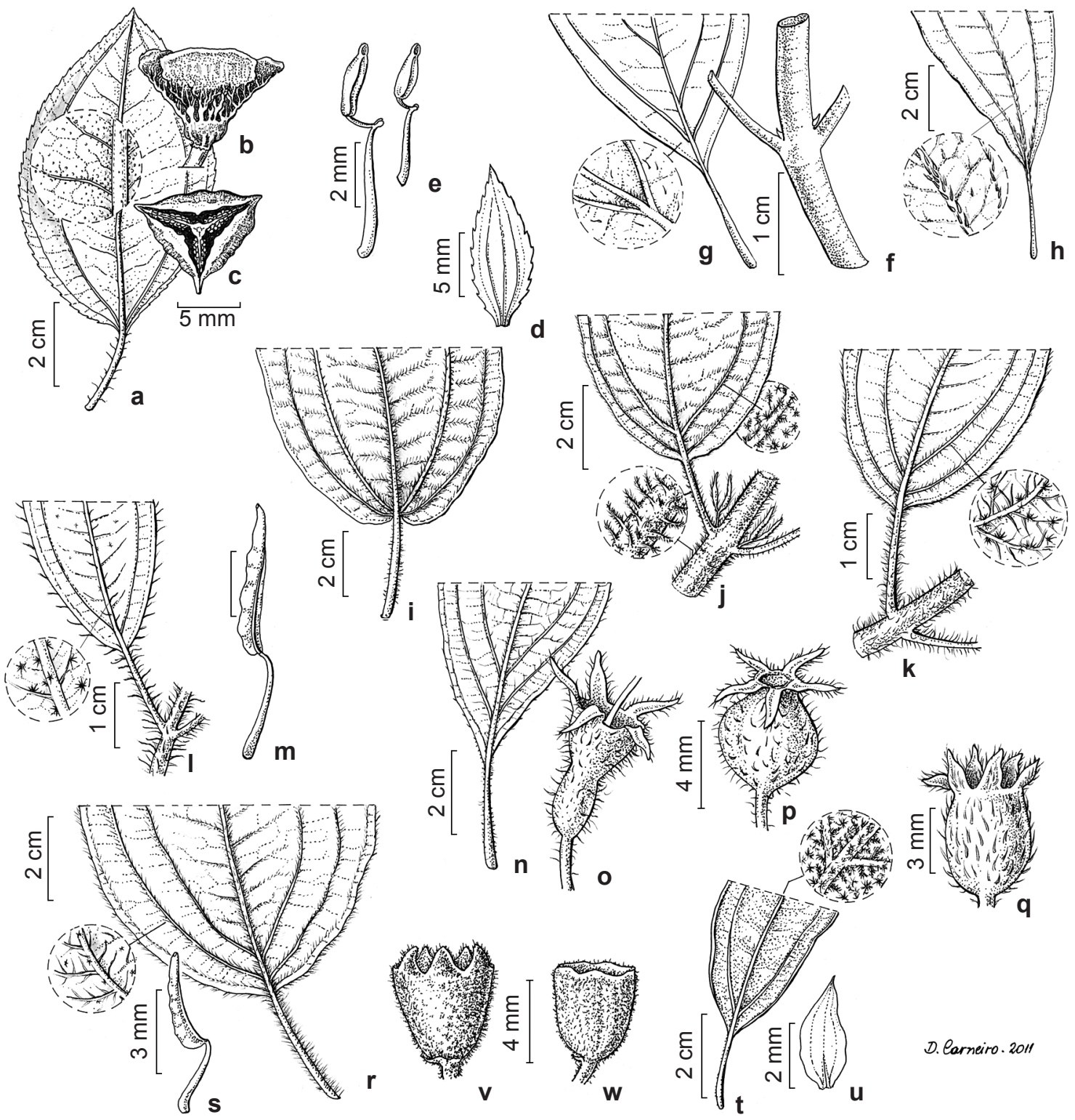

D. Carneiro. 2011

Figura 1 - a-c. Bertolonia mosenii - a. face abaxial da folha com detalhe do indumento; b-c. frutos (Fraga et al. 2249). d-e. Lavoisiera imbricata - d. folha; e. estames (Fontana et al. 5377). f-g. Leandra acutiflora - f. ramo; g. face adaxial da folha com detalhe do indumento (Meirelles et al. 477). h. L. aspera - face abaxial da folha com detalhe do indumento (Kollmann et al. 10578). i. L. aurea - face abaxial da folha (Meirelles et al. 443). j. L. carassana - ramo e face abaxial folha com detalhe do indumento (Meirelles et al. 285). k. L. foveolata - face abaxial da folha com detalhe do indumento (L. Kollmann 6376). 1-m. L. gardneriana - 1. face abaxial da folha com detalhe do indumento; m. estame (Goldenberg et al. 1275). n-p. L. longisetosa - n. face abaxial da folha; o. hipanto; p. fruto (Goldenberg et al. 1190). q. L. melastomoides - hipanto (Amorim et al. 7829). r-s. L. nianga - r. face abaxial da folha com detalhe do indumento; s. estame (Labiak et al. 4961). t-w. L. tomentosa - t. face abaxial da folha com detalhe do indumento; u. pétala; v. hipanto; w. fruto (Kollmann \& Kollmann 7008). Figure 1 - a-c. Bertolonia mosenii - a. abaxial surface of the leaf with detail of indument; b-c. fruits (Fraga et al. 2249). d-e. Lavoisiera imbricata - d. leaf; e. stamens (Kollmann et al. 10578). f-g. Leandra acutiflora - f. branch; g. adaxial surface of the leaf with detail of indument (Meirelles et al. 477). h. L. aspera - adaxial surface of the leaf with detail of indument (Kollmann et al. 10578). i. L. aurea - abaxial surface of the leaf (Meirelles et al. 443). j. L. carassana - branch and abaxial surface of the leaf with detail of indument (Meirelles et al. 285). k. L. foveolataabaxial surface of the leaf with detail of indument (L. Kollmann 6376). 1-m. L. gardneriana-1. abaxial surface of the leaf with detail of indument; m. stamen (Goldenberg et al. 1275). n-p. L. longisetosa - n. abaxial surface of the leaf; o. hypanthium; p. fruit (Goldenberg et al. 1190). q. L. melastomoides - hypanthium (Amorim et al. 7829). r-s. L. nianga - r. abaxial surface of the leaf with detail of indument; s. stamen (Labiak et al. 4961). t-w. L. tomentosa - t. abaxial surface of the leaf with detail of indument; u. petal; v. hypanthium; w. fruit (Kollmann \& Kollmann 7008). 
com esparsos tricomas concentrados em sua maioria na inserção das nervuras secundárias com a central, formando domácias, nervuras $3+2$, suprabasais. Panícula 8,4-22,5 cm compr., terminal e pseudolateral. Flores 5-meras; hipanto 3-3,3 mm compr., campanulado, glabro; cálice duplo, persistente; lacínias internas não diferenciadas, as externas formadas por dentículos; pétalas brancas, longamente triangulares, ápice agudo; estames 10, isomórficos, conectivo prolongado $0,2-0,3 \mathrm{~mm}$ abaixo das tecas, inapendiculado, anteras 1,6-1,9 mm compr., brancas, oblongas em vista ventral, arredondadas em vista lateral, ápice truncado, poro apical único; ovário 2/3 ínfero, glabro, 3-locular; estilete 5,1-5,5 mm compr., reto, glabro. Baga; sementes numerosas, piramidal-arredondadas.

Material examinado: Balança, 21.V.2010, fr., J. Meirelles et al. 477 (MBML, RB).

Material adicional examinado: BRASIL. PARANÁ: Morretes, Serra da Graciosa, 12.XII.2007, fl., E. Camargo 178 (UPCB).

Leandra acutiflora corre em MG, ES, SP, RJ, PR, SC. No PEFG foi encontrado apenas um indivíduo em Floresta Ombrófila Densa Montana. Distingue-se pelos ramos e folhas com face adaxial glabros. A face abaxial das folhas possui tufos de tricomas, formando domácias, na inserção da nervura central.

\section{Leandra aspera Cogn., Monogr. Phan. 7: 655.} 1891.

Fig. 1h

Arbusto ca. $2 \mathrm{~m}$ alt.; ramos cilíndricos, revestidos por tricomas simples de base alargada. Folhas com pecíolo 0,4-1,7 cm compr.; lâmina $2-10 \times 1-4,5 \mathrm{~cm}$, lanceolada a elíptica, base aguda a arredondada, margem curto serreada a inteira, pouco sinuosa, ápice acuminado, face adaxial esparsamente revestida por tricomas simples de base alargada, adpressos, face abaxial moderadamente revestida por tricomas simples, nervuras $3+2$, basais. Panícula 3-8 cm compr., terminal. Flores 5-meras; hipanto ca. 3,3 mm compr., campanulado, densamente revestido por tricomas simples; cálice duplo, persistente; lacínias internas largamente triangulares, as externas lineares; pétalas brancas, lanceoladas, ápice agudo; estames 10, isomórficos, conectivo prolongado 0,3-0,4 $\mathrm{mm}$ abaixo das tecas, apêndices dorsais, bilobados ou bífidos; anteras 3-4 mm compr., rosadas, falciformes, ápice arredondado, poro apical único; ovário $1 / 2$ a $2 / 3$ ínfero, revestido por tricomas simples de base alargada, 3-locular; estilete 0,9-1,2 cm compr., reto, glabro. Baga; sementes numerosas, piramidais.
Material examinado: Balança, 12.II.2008, fl., L. Kollmann et al. 10578 (MBML, UPCB). Vale ao lado do pasto, à direita da entrada do parque, 9.IV.2009, fr., J. Meirelles et al. 300 (CEPEC,MBML, RB, UPCB).

Leandra aspera ocorre no RJ e ES, sendo este o primeiro registro para este estado. No PEFG ocorre em Floresta Ombrófila Densa Montana em uma população pequena e esparsa. Assemelha-se a L. aurea (Cham.) Cogn. pelas nervuras basais e anteras rosadas, mas difere pelas nervuras em número de $3+2$ e inflorescências mais curtas (3-8 cm compr. em $L$. aspera; 9,5-16 cm compr. em $L$. aurea). Os exemplares analisados diferem pouco entre si, pois o espécime L. Kollmann et al. 10578 possui inflorescências menos desenvolvidas do que $J$. Meirelles et al. 300 e folhas com base aguda, enquanto o segundo material possui folhas com base obtusa.

5. Leandra aurea (Cham.) Cogn., Fl. bras. 14(4): 142. 1886.

Fig. 1i

Arbusto ca. 1,5 m alt.; ramos sub-cilíndricos a cilíndricos, densamente revestidos por tricomas simples. Folhas com pecíolo 0,3-1,3 cm compr.; lâmina 4,3-13,5 × 1,4-4 cm, oval-oblonga, base arredondada, levemente cordada, margem inteira, ápice acuminado, ambas as faces densamente revestidas por tricomas simples, face abaxial moderadamente revestida por tricomas estrelados, nervuras 5+2, basais. Panícula 9,5-16 cm compr., terminal. Flores 5-meras; hipanto 3,8-4,6 cm compr., oblongo, densamente revestido por tricomas simples; cálice duplo, persistente; lacínias internas não claramente diferenciadas, as externas longo-triangulares a oblongas; pétalas brancas, ovais a ovais-oblongas, ápice agudo; estames 10 , levemente dimórficos, conectivo não prolongado abaixo das tecas, inapendiculado, anteras 3-3,6 mm compr., rosadas, oblongas em vista ventral, ápice arredondado, poro apical único; ovário 1/2 ínfero, densamente revestido por tricomas simples, 3-locular; estilete 8,5-10 mm compr., reto, glabro. Baga; sementes numerosas, piramidais-alongadas. Material examinado: entre as Piscinas e o Mirante, 7.IV.2009, fr., J. Meirelles et al. 279 (CEPEC, MBML, RB, UPCB); trilha para o Mirante, 18.V.2010, fl., J. Meirelles et al. 443 (MBML, RB, UPCB).

Leandra aurea pode ser encontrada nos estados da BA, MG, SP, RJ, ES (primeiro registro), PR, SC, RS. Também ocorre na Bolívia (Cogniaux, 1891). No PEFG ocorre às margens da Floresta Ombrófila Densa Montana, sendo relativamente comum em trilhas expostas ao sol. Assemelha-se a L. gardneriana Cogn. e L. nianga Cogn. pelo hábito 
e porte em campo. Difere-se pelas anteras rosadas e pelos tricomas consideravelmente menores e mais densos. Ver comentários em L. aspera.

6. Leandra carassana (DC.) Cogn., Fl. bras. 14(4): 120. 1886

Fig. $1 \mathrm{j}$

Arbusto 2-2,5 m alt.; ramos sub-cilíndricos a quadrangulares, compressos, densamente revestidos por tricomas dendríticos, os ramos mais velhos glabrescentes. Folhas com pecíolo 1-9,5 cm compr.; lâmina 5-24 × 2-13,5 cm, oval, base obtusa a arredondada, margem crenulada, ápice acuminado, face adaxial moderadamente revestida por tricomas simples, face abaxial moderadamente revestida por tricomas estrelado-estipitados e densamente revestida por tricomas dendríticos nas nervuras; nervuras $5+2$ a $7+2$, suprabasais. Panícula 5-19 cm compr., terminal. Flores 5-meras; hipanto 2,5-4,5 mm compr., urceolado, densamente revestido por tricomas dendríticos, delgados; cálice duplo, persistente; lacínias internas largamente triangulares, as externas estreito-triangulares; pétalas brancas, oblongo-triangulares, ápice agudo; estames 10, isomórficos, conectivo prolongado $0,2-0,4 \mathrm{~mm}$ abaixo das tecas, inapendiculado; anteras $2,5-3,1 \mathrm{~mm}$ compr., rosadas, falciformes em vista lateral, ápice agudo, poro apical único; ovário $1 / 2$ ínfero, densamente revestido por tricomas dendríticos curto ramificados, 3-locular; estilete 4,7-7,5 mm, reto, glabro. Baga; sementes numerosas, ovais-alongadas.

Material examinado: s. 1., 25.III.2005, fr., L. Kollmann et. al. 7567 (MBML, UPCB); s.1., 25.III.2005, fr., $L$. Kollmann et. al. 7569 (MBML, UPCB); atrás do Mirante, 7.IV.2009, fl., J. Meirelles et al. 285 (CEPEC, MBML, UPCB); Forninho, 20.V.2010, fl., J. Meirelles et al. 467 (MBML, RB, UPCB); 20.V.2010, fl. e fr., J. Meirelles et al. 469 (MBML, RB, UPCB); arredores do alojamento, mata do Klaus, 21.V.2010, fr., J. Meirelles et al. 485 (MBML, RB).

Leandra carassana ocorre nos estados de MG, ES, SP, RJ, PR, SC, RS. Também ocorre na Bolívia (Cogniaux, 1891). No PEFG é bem distribuída em populações pequenas em Floresta Ombrófila Densa Montana e Alto-montana. Distingue-se pelos ramos densamente revestidos por tricomas dendríticos macios que se soltam facilmente.

7. Leandra foveolata (DC.) Cogn., Fl. bras. 14(4): 100. 1886.

Fig. 1k

Arbusto 1-2,5 m alt.; ramos cilíndricos, moderadamente a esparsamente revestidos por tricomas simples, as partes mais velhas glabrescentes. Folhas com pecíolo 0,5-3,4 cm compr.; lâmina 4,5-11,5 × 1,5-4,5 cm, ovallanceolada, base obtusa a sub-cordada, margem curto-serreada, ápice acuminado, face adaxial moderadamente revestida por tricomas simples de base levemente alargada, face abaxial densamente revestida por tricomas simples, com tricomas estrelados e dendríticos sobre as nervuras; nervuras 5+2, suprabasais. Panícula (4)6-15 cm compr., terminal. Flores 5-meras; hipanto 3,4-6 mm compr., campanulado, revestido por tricomas simples e longos e tricomas dendríticos e estrelados; cálice duplo, persistente; lacínias internas largamente triangulares, as externas oblongas a subuladas; pétalas brancas, lanceoladas a ovais, ápice agudo, apiculado; estames 10 , isomórficos, conectivo prolongado ca. $0,2 \mathrm{~mm}$ abaixo das tecas, apêndices dorsais, bi-tuberculados inconspícuos; anteras 2-4 $\mathrm{mm}$ compr., rosadas, subuladas, ápice arredondado, poro apical único; ovário $2 / 3$ ínfero, moderadamente revestido por tricomas simples no ápice, 3-locular; estilete ca. $1 \mathrm{~cm}$ compr., reto, glabro. Baga; sementes numerosas, ovais a ovais-alongadas.

Material examinado: 12.X.2000, fl. e fr., L. Kollmann \& C.N. Fraga 3137 (MBML, UPCB); 27.II.2004, fr., L. Kollmann 6376 (MBML, UPCB); 4.IX.2004, fr., $L$. Kollmann \& R.L. Kollmann 6970 (MBML, UPCB); 30.X.2004, fl., L. Kollmann et. al. 7169 (MBML, UPCB); 25.III.2005, fl., L. Kollmann 7568 (MBML, UPCB); trilha para as Piscinas, 2.V.2008, fl. e fr., R. Goldenberg 1051 (UPCB*); entre as Piscinas e o Mirante, 7.IV.2009, fl., J. Meirelles et al. 280 (UPCB*); trilha para as Piscinas, próximo ao primeiro afloramento rochoso, 18.V.2010, fl., J. Meirelles et al.441 (MBML, RB, UPCB).

Leandra foveolata ocorre em MG, ES, SP, RJ, PR. Também ocorre nas Guianas (Cogniaux 1891). No PEFG é comum e ocorre em várias localidades com populações de tamanho médio às margens de Floresta Ombrófila Densa Montana. Distingue-se de L. gardneriana e L. nianga pelas anteras rosadas e de $L$. aurea pelas nervuras suprabasais.

8. Leandra gardneriana Cogn., Fl. bras. 14(4): 95. 1886.

Fig. 11-m

Arbusto a arbusto escandente ca. $1 \mathrm{~m}$ alt.; ramos cilíndricos, densamente revestidos por tricomas simples, eretos. Folhas com pecíolo $0,5-2,3 \mathrm{~cm}$ compr.; lâmina 3,5-12 × 0,8-4 cm, oval a oval-lanceolada, base aguda a arredondada, margem inteira, ápice agudo, face adaxial esparsamente revestida por tricomas simples, face abaxial esparsamente a moderadamente revestida por tricomas estrelados principalmente sobre as 
nervuras, nervuras 3+2, suprabasais. Panícula 9-15,5 cm compr., terminal. Flores 5-meras; hipanto 5,3-5,8 $\mathrm{mm}$ compr., urceolado com forte constrição acima do ovário moderadamente revestido por tricomas simples e estrelados; cálice duplo, persistente; lacínias internas largamente triangulares, as externas triangulares com ápice agudo; pétalas brancas, obovado-oblongas ou ovais-oblongas, ápice agudo; estames 10 , isomórficos, conectivo não prolongado abaixo das tecas, inapendiculado; anteras 5-5,8 mm compr., amarelas, lineares subuladas, ápice agudo, poro apical único; ovário ínfero, glabro, 3-locular; estilete 8-10,6 mm compr., reto, glabro. Baga; sementes numerosas, ovais.

Material examinado: 27.I.2004, fl. e fr., L. Kollmann 6391 (MBML, UPCB); brejo próximo à sede, 20.I.2009, fl. e fr., R. Goldenberg et al. 1275 (UPCB*); entre as Piscinas e o Mirante, 7.IV.2009, fl. e fr., J. Meirelles et al. 289 (UPCB*); estrada para o PEFG, 19.V.2010, fr., J. Meirelles et al. 457 (MBML, RB, UPCB).

Leandra gardneriana ocorre nos estados da BA, MG, ES, SP, RJ. No PEFG ocorre em Floresta Ombrófila Aberta Montana e úmida em populações pequenas. Distingue-se pelo hipanto pronunciadamente urceolado com forte constrição acima do ovário e por alguns indivíduos possuírem hábito escandente.

9. Leandra longisetosa Cogn., Fl. bras. 14(4): 181. 1886.

Fig. 1n-p

Arbusto 1,8-2 m alt.; ramos cilíndricos a compressos e canaliculados, revestidos por tricomas simples e eretos, de ápice encurvado, as partes mais velhas glabrescentes. Folhas com pecíolo $2-3,2 \mathrm{~cm}$ compr.; lâmina 13-20 × 6-6,5 cm, oval-elíptica, base atenuada a decurrente, margem curto-serreada a denteada, ápice atenuado a agudo, face adaxial moderadamente revestida por tricomas simples prostrados, face abaxial moderadamente revestida por tricomas simples de ápice encurvado e estrelados sobre as nervuras secundárias, nervuras $5+2$ a $7+2$, suprabasais. Panícula $4-8 \mathrm{~cm}$ compr., terminal. Flores 5-meras; hipanto 3,9-4,8 mm compr., campanulado a urceolado, moderadamente a densamente revestido por tricomas simples e estrelados; cálice duplo, persistente; lacínias externas longo-triangulares ou subuladas, as internas largamente triangulares; pétalas brancas, lanceoladas, ápice acuminado; estames 10, isomórficos, conectivo não prolongado abaixo das tecas, inapendiculado; anteras 1,8-3 mm compr., brancas, oblongas, ápice levemente truncado, poro apical único; ovário ínfero, glabro e denteado, 3-locular; estilete 9-10 mm compr., reto, glabro. Baga; sementes numerosas, ovais alongadas a piramidais.

Material examinado: 30.X.2004, fl. e fr., L. Kollmann et al. 7216 (MBML); trilha da Balança, 18.VII.2008, fl., R. Goldenberg et al. 1179 (MBML, RB, UPCB); trilha para Goela da Onça, 19.VII.2008, fl., R. Goldenberg et al. 1190 (MBML, RB, UPCB); trilha da Balança, 21.V.2010, fl., J. Meirelles et al. 478 (RB, MBML).

Material adicional examinado: BRASIL. PARANÁ: Campina Grande do Sul, Alto da Serra, 25.VIII.1957, fl., G. Hatschbach 4067 (UPCB).

Leandra longisetosa ocorre em MG, ES, RJ, PR. No PEFG é representada por uma pequena população que ocorre em Floresta Ombrófila Densa Alto-montana. Distingue-se pelas folhas com base atenuada a decurrente e pelos pecíolos e lacínias avermelhados.

10. Leandra melastomoides Raddi, Mem. Mat. Fis. Soc. Ital. Sci. Modena, Pt. Mem. Fis. 18(2): 386. 1820.

Fig. $1 \mathrm{q}$

Arbusto 1-2 m alt.; ramos sub-cilíndricos, revestidos por tricomas simples de base alargada e ápice encurvado. Folhas com pecíolo 3,5-10 mm compr.; lâmina $6,8-16,5 \times 1,5-4,2 \mathrm{~cm}$, lanceolada, base atenuada a arredondada, margem curto serrilhada, ápice agudo a arredondado, face adaxial densamente revestida por tricomas simples de base alargada e ápice encurvado, face abaxial moderadamente revestida por tricomas simples de base alargada, nervuras $3+2$, suprabasais. Panícula 5-7 cm compr., terminal. Flores 6-meras; hipanto 4-4,5 mm compr., campanulado, densamente revestido por tricomas simples de base alargada; cálice duplo, persistente; lacínias internas largamente triangulares a oblongas, as externas subuladas; pétalas brancas, estreitamente triangulares, ápice agudo apiculado; estames 12, isomórficos, conectivo prolongado 0,5-2 $\mathrm{mm}$ abaixo das tecas, inapendiculado; anteras 2,7-3,7 mm compr., amareladas in sicco, oblongas, ápice arredondado, poro apical único; ovário 1/2 ínfero, densamente revestido por tricomas simples e eretos, 4-locular; estilete 1-1,1 cm compr., curvo, glabro. Baga; sementes numerosas, oval-alongadas a piramidais.

Material examinado: 24.I.1973, fl., (MBML 835, UPCB); brejo próximo da sede do Parque, 1.V.2008, fr., C.N. Fraga et. al 1954 (UPCB); trilha da Balança, 21.V.2010, fr., J. Meirelles et al. 480 (UPCB*).

Material adicional examinado: BRASIL. ESPÍRITO SANTO: Santa Leopoldina, Bragança, 30.X.2006, fl., L.F.S. Magnago et al. 1478 (UPCB). 
Leandra melastomoides ocorre nos estados da PB, BA, GO, DF, MG, ES, SP. Segundo Wurdack (1962) ocorre também no Suriname. No PEFG é representada por poucos indivíduos encontrados em poucas localidades em Floresta Ombrófila Densa Montana e Alto-montana. Assemelha-se a L. carassana pelas panículas capitadas com flores congestas, porém, diferencia-se pelas folhas lanceoladas e pelas flores 6-meras.

11. Leandra nianga Cogn., Fl. bras. 14(4): 96. 1886.

Fig. 1r-s

Arbusto 0,5-2 $\mathrm{m}$ alt.; ramos quadrangulares a sub-cilíndricos, densamente revestidos por tricomas simples e eretos. Folhas com pecíolo 1,23,4 cm compr.; lâmina 5,8-15,5 × 2,2-6,5 cm, ovaloblonga, base obtusa a arredondada ou subcordada, margem inteira a crenulada, ápice acuminado ou agudo, face adaxial moderadamente revestida por tricomas simples prostrados e tricomas dendríticos na nervura central, face abaxial moderadamente revestida por tricomas simples, eretos, de ápice encurvado e tricomas estrelados principalmente sobre as nervuras, nervuras $5+2$, suprabasais. Panícula 6,5-15 cm compr., terminal. Flores 5-meras; hipanto 4-4,5 mm compr., oblongo a levemente urceolado, densamente revestido por tricomas simples e eretos; cálice duplo, persistente; lacínias externas subuladas, as internas largamente triangulares; pétalas brancas, branco-esverdeadas ou rosadas, lanceoladas, ápice agudo; estames 10, isomórficos, conectivo não prolongado abaixo das tecas, inapendiculado; anteras 2,6-3,1 mm compr., amarelas, oblongas, ápice arredondado a levemente truncado, poro apical único; ovário ínfero, glabro, 4-locular; estilete 8,2-9,7 mm compr., reto, glabro. Baga; sementes numerosas, piramidais.

Material examinado: Rio Manso, 15.X.2008, fl., P. Labiak et al. 4961 (MBML, UPCB); estrada entre Rio Manso e Balança, 16.X.2008, fl., C.N. Fraga et al. 2261 (UPCB).

Material adicional examinado: BRASIL. ESPÍRITO SANTO: São Roque do Canaã, Alto Misterioso, 16.IX.2005, fl., L. Kollmann et al. 8306 (UBPC); 25.XI.2007, fl., M. Simonelli et al. 1371 (UPCB). Santa Maria de Jetibá, Rio das Pedras, 10.XII.2002, fl. e fr., $L$. Kollmann et al. 5845 (UPCB).

Leandra nianga ocorre nos estados de MG, ES, SP, RJ. No PEFG ocorre em apenas uma localidade onde é representada por poucos indivíduos, em Floresta Ombrófila Densa Montana. Assemelha-se a L. gardneriana pelos ramos densamente revestidos por tricomas simples e pelas anteras amarelas. Diferencia-se pelas folhas com nervuras em número de $5+2$ e pelas anteras menores (2,6-3,1 mm compr.).
12. Leandra tomentosa Cogn., Fl. bras. 14(4): 609. 1888.

Fig. 1t-w

Arbusto ca. 0,5-3 m alt.; ramos cilíndricos; ramos jovens, ambas as faces das folhas e hipanto densamente recobertos por tricomas estrelados com braços longos, persistente na face abaxial das folhas, caduco nos frutos, ramos mais velhos e na face adaxial das folhas. Folhas com pecíolo 0,5-1,7 cm compr.; lâmina 2,4-7 × 1-2,8 cm, oblongolanceolada, base aguda, margem revoluta, ápice agudo, nervuras 5, suprabasais. Panícula 2,1-6 cm compr., terminal. Flores 5-meras; hipanto 2-3,4 mm compr., campanulado; cálice duplo, caduco; lacínias internas triangulares, externas espessadas, oblongas e curtamente subuladas, eretas; pétalas brancas, ovais, ápice acuminado; estames 10, isomórficos, conectivo prolongado $0,7-1 \mathrm{~mm}$ abaixo das tecas, inapendiculado, dorsalmente espessado e levemente giboso na região mediana da antera, anteras ca. $3 \mathrm{~mm}$ compr., beges, oblongas em vista ventral, dorsalmente arqueadas, ápice arredondado, poro apical único; ovário 1/2 ínfero, glabro, 3-locular, estilete ca. 7,4 mm compr., reto, glabro. Baga; sementes numerosas, ovóides a ovóide-alongadas.

Material examinado: Forno Grande, 12.VIII.1948, fl. e fr., A.C. Brade 19253 (RB); Forninho, 5.IX.2004, fl. e fr., L. Kollmann \& R.L. Kollmann 7008 (MBML, UPCB); Forno Grande, 19.VII.2007, fl. e fr., L. Kollmann 9967 (MBML, UPCB); Forninho, 21.I.2009, fr., R. Goldenberg et al. 1284 (RB, MBML, UPCB, CEPEC); 20.V.2010, fl. e fr., J. Meirelles et al. 470 (MBML, RB, UPCB); 20.V.2010, fr., J. Meirelles et al. 471 (MBML, RB, UPCB).

Leandra tomentosa ocorre nos estados do RJ, ES (primeiro registro). No PEFG é representada por uma pequena população restrita as áreas elevadas como o Pico do Forno Grande, a aproximadamente $1.660 \mathrm{~m}$ de altitude e do Forninho com $1.600 \mathrm{~m}$, em afloramentos rochosos inseridos em Floresta Ombrófila Densa Alto-montana. Pode ser reconhecida pelos ramos, folhas e hipanto densamente revestidos por tricomas estrelados longo ramificados.

\section{Leandra sp 1.}

Fig. 2a

Arbusto; ramos cilíndricos, densamente revestidos por tricomas simples de base alargada, encurvados. Folhas com pecíolo 0,9-1,6 cm compr.; lâmina 7,5-10,7 $\times 2-3,7 \mathrm{~cm}$, oval-lanceolada, base atenuada, margem levemente serreada, ápice acuminado, ambas as faces densamente revestidas por tricomas simples, na adaxial encurvados, na abaxial enovelados, nervuras $3+2$ a 5+2, suprabasais. Panícula 4-6,8 cm compr., laterais e terminais. Flores não visualizadas, cálice persistente, 5-mero. Baga; sementes numerosas, piramidais-alongadas com vértices arredondados. 


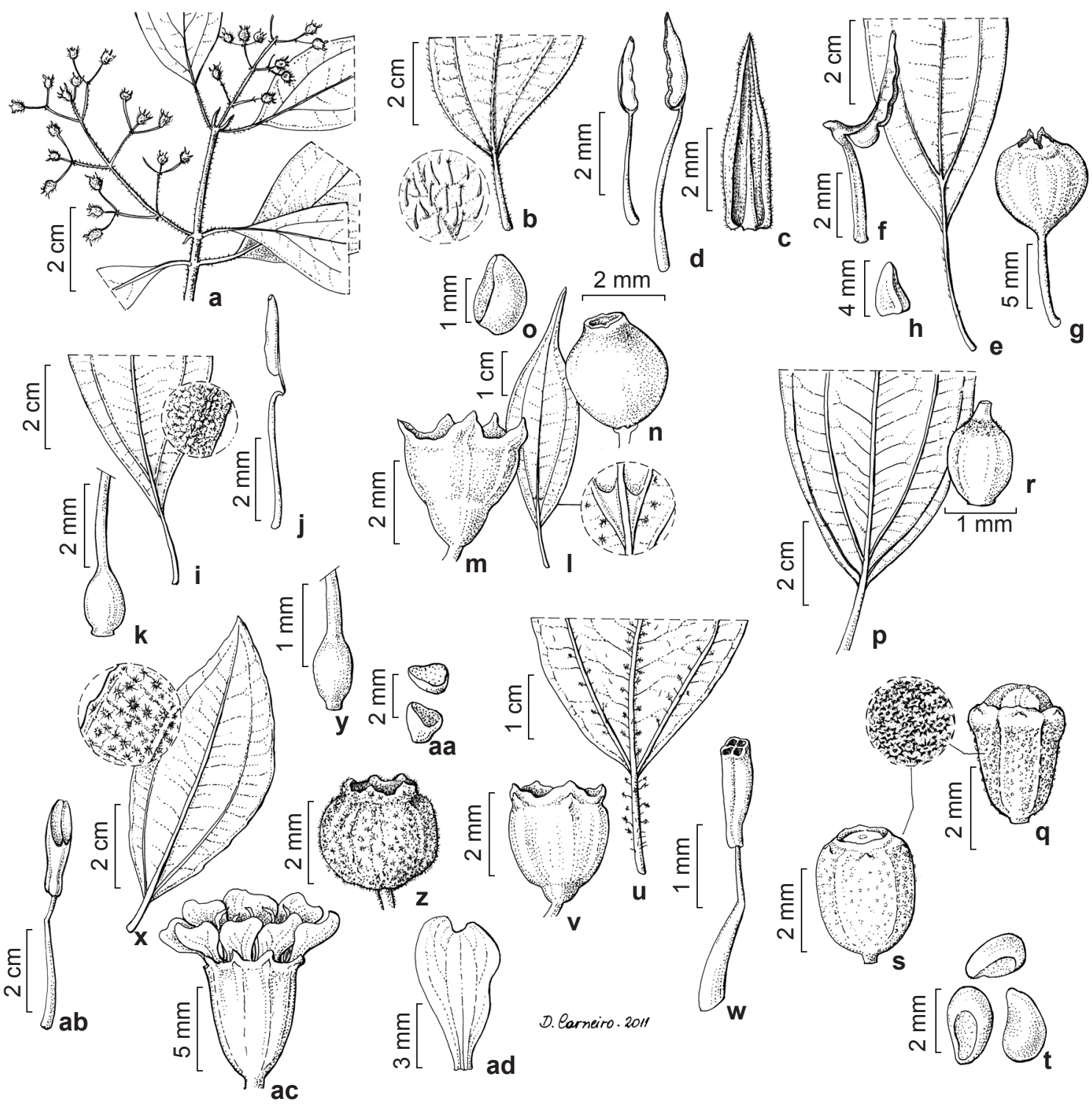

Figura 2 - a. Leandra sp. 1 - ramo e inflorescências (Kollmann \& Kollmann 6647). b. Leandra sp. 2 - face adaxial de folha jovem com detalhe do indumento (Forzza et al. 4992). c-d. Marcetia taxifolia - c. folha; d. estames (Fontana et al. 5378). e-h. Meriania tetramera - e. folha; f. estame; g. fruto; h. semente (Goldenberg et al. 1185). i-k. M. chartacea -i. face abaxial da folha com detalhe do indumento (Goldenberg et al. 1174); j. estame; k. ovário (Santos 783). 1-o. M. doriana -1 . face abaxial da folha com detalhe das domácias e indumento; $\mathrm{m}$. hipanto; $\mathrm{n}$. fruto; o. semente (Kollmann et al. 10588). p-t. M. formosa - p. folha; q. hipanto (em botão) com detalhe do indumento; r. ovário; s. fruto; t. sementes (Goldenberg et al. 1180). u-w. M. hirtella - u. folha; v. hipanto; w. estame (Fraga et al. 2225). x-aa. M. kriegeriana - x. folha com detalhe do indumento; y. ovário e base do estilete; z. fruto; aa. sementes (Kollmann 6378). ab. M. latecrenata - estame (Kollmann \& Kollmann 6611). ac-ad. M. octopetala - ac. flor; ad. pétala (Meirelles et al. 497). Figure 2 - a. Leandra sp. 1 - branch and inflorescences (Kollmann \& Kollmann 6647). b. Leandra sp. 2 - adaxial surface of the young leaf with detail of indument (Forzza et al. 4992). c-d. Marcetia taxifolia - c. leaf; d. stamens (Fontana et al. 5378). e-h. Meriania tetramera - e. leaf; f. stamen; g. fruit; h. seed (Goldenberg et al. 1185). i-k. M. chartacea - i. abaxial surface of leaf with detail of indument (Goldenberg et al. 1174); j. stamen; k. ovary (Santos 783). 1-o. M. doriana -1. abaxial surface of the leaf with detail of domatia and indument; m. hypanthium; n. fruit; o. seed (Kollmann et al. 10588). p-t. M. formosa - p. leaf; q. hypanthium (in bud) with detail of indument; r. ovary; s. fruit; t. seeds (Goldenberg et al. 1180). u-w. M. hirtella - u. leaf; v. hypanthium; w. stamen (Fraga et al. 2225). $\mathrm{x}$-a. M. kriegeriana $-\mathrm{x}$. leaf with detail of indument; $\mathrm{y}$. ovary and style base; z. fruit; aa. seeds (Kollmann 6378). ab. M. latecrenata stamen (Kollmann \& Kollmann 6611). ac-ad. M. octopetala - ac. flower; ad. petal (Meirelles et al. 497). 
Material examinado: 10.IV.2004, fr., L. Kollmann \& R.L. Kollmann 6647 (MBML, UPCB).

Leandra sp. 1 é, aparentemente, endêmica do estado do ES. Distingue-se das demais espécies do gênero coletadas na UC pelas inflorescências terminais e laterais. A identificação em nível de espécie não foi possível devido à falta de material com flor e a complexidade do grupo.

\section{Leandra sp 2.}

Fig. 2b

Arvoreta ca. $4 \mathrm{~m}$ alt.; ramos cilíndricos, canaliculados nas extremidades, densamente revestidos por tricomas simples, um pouco sinuosos. Folhas com pecíolo 0,5-4,2 cm compr.; lâmina 3-18 × 1-6,6 cm, oval-oblonga, base aguda, margem levemente serreada, ápice acuminado, face adaxial das folhas jovens moderadamente revestida por tricomas simples e estrelados estipitados, as folhas adultas são moderadamente revestidas apenas por tricomas simples, face abaxial moderadamente revestida por tricomas simples e tricomas estrelados nas nervuras, nervuras 5+2 a 7+2, suprabasais. Panícula ca. 7,4 cm compr., terminal. Flores não visualizadas, cálice caduco. Baga; sementes numerosas, piramidais com vértices arredondados, alongadas.

Material examinado: Balança, 13.II.2008, fr., R.C. Forzza et al. 4992 (UPCB).

Leandra sp. 2 é, aparentemente, endêmica do ES. No PEFG ocorre em apenas uma localidade em Floresta Ombrófila Densa Alto-montana. Dentre as espécies de Leandra coletadas na UC distingue-se por ser uma arvoreta de cerca de $4 \mathrm{~m}$ alt., enquanto as demais são arbustos, ou mais raramente, arbustos escandentes. A identificação em nível de espécie não foi possível devido à falta de material com flor.

15. Marcetia taxifolia (A.-St. Hil.) DC., Prodr. 3:
$\begin{aligned} & \text { 124. } 1828 . \\ & \text { Fig } 2 \mathrm{c}-\mathrm{d}\end{aligned}$

Arbusto 0,7-1 $\mathrm{m}$ alt.; ramos sub-cilíndricos, as partes mais jovens quadrangulares e densamente revestidas por tricomas glandulares, principalmente nos nós, as mais velhas glabras. Folhas com pecíolo 0,2-0,6 mm compr.; lâmina 3-7,5 × 1,3-3 mm, cordiforme, base cordada, margem revoluta, ápice agudo, ambas as faces densamente revestidas por tricomas glandulares, nervuras 3, basais. Flores solitárias, laterais. Flores 4-meras; hipanto 2-2,5 mm compr., campanulado, moderadamente revestido por tricomas glandulares; cálice simples, persistente; lacínias subuladas; pétalas brancas, lanceoladas, ápice agudo; estames 8, levemente dimórficos, conectivo não prolongado abaixo das tecas, apêndices ventrais levemente bilobados; anteras 3,2-3,8 mm compr., amarelas, oblongas, ápice arredondado, poro apical único; ovário $2 / 3$ súpero, glabro, 4-locular; estilete 7-8 mm compr., reto, glabro. Cápsula; sementes numerosas, cocleadas.

Material examinado: inselberg por baixo do Mirante, beira do pasto, 16.VII.2008, fl. e fr., A.P. Fontana et al. 5378 (MBML, UPCB); inselberg por baixo do Mirante, acima do pasto, 9.IV.2009, fr., J. Meirelles et al. 297 (UPCB*); 22.V.2010, fr., J. Meirelles et al. 488 (UPCB*). Material adicional examinado: BRASIL. ESPÍRITO SANTO: Santa Maria do Jetibá, Pedra do Garrafão, 18.VII.2007, fl. e fr., P. Labiak \& A.P. Fontana 4191 (UPCB). São Roque do Canaã,Alto Misterioso, 25.VI.2007, fl. e fr., R.C. Britto et al. 186 (MBML, UPCB).

Marcetia taxifolia é amplamente distribuída, ocorrendo nos estados de RO, CE, PB, PE, BA, AL, SE, DF, MG, ES, SP, RJ, PR. Também ocorre na Colômbia (Mendoza \& Ramires 2006), Venezuela e Guiana (Martins 2009). No PEFG ocorre apenas em afloramentos rochosos expostos ao sol, inseridos em Floresta Ombrófila Densa Montana. Distingue-se pelas folhas adultas menores que $1 \mathrm{~cm}$ de comprimento, pelas folhas com base cordada e pelas pétalas brancas.

16. Meriania tetramera Wurdack, Phytologia 45(4): 324. 1980.

Fig. 2e-h

Arvoreta ca. $5 \mathrm{~m}$ alt. a árvore $18 \mathrm{~m}$ alt.; ramos cilíndricos, revestidos por tricomas amorfos a glabros. Folhas com pecíolo 0,5-5,4 cm compr.; lâmina 5,2-17 × 1,8-5,5 cm, elíptico-lanceolada a lanceolada, base aguda, margem denteada, serreada ou inteira, ápice levemente acuminado, face adaxial glabra, face abaxial moderadamente revestida por tricomas amorfos, adpressos, a glabra, nervuras $3+2$, suprabasais. Umbela 5-7,5 cm compr., terminal. Flores 4-meras; hipanto 3-4,8 mm compr., campanulado, revestido por indumento amorfo; cálice duplo, persistente, inconspícuo; lacínias internas largamente triangulares, as externas lineares, diminutas; pétalas brancas, rosadas ou verde-claras com ápice arroxeado, obovadas, ápice retuso a acuminado; estames 8 , isomórficos, conectivo prolongado 1,2-2,4 mm abaixo das tecas, apêndices dorsais, agudos; anteras 4,9-8,1 mm compr., amarelas a avermelhadas, subuladas, ápice arredondado, poro apical único; ovário súpero, glabro, 4-locular; estilete 1,1-1,8 cm compr., curvo, glabro. Cápsula; sementes numerosas, piramidais a piramidal-alongadas.

Material examinado: trilha da Balança, 18.VII.2008, fl., fl. e fr., R. Goldenberg et al. 1185 (MBML, RB, UPCB); arredores do alojamento, mata do Klaus, 21.V.2010, fl., J. Meirelles et al. 484 (UPCB*). 
Material adicional examinado: BRASIL. ESPÍRITO SANTO: Conceição do Castelo, Ribeirão do Meio, 14.VI.1985, fl., fl. e fr., G. Hatschbach 49403 (UPCB); Venda Nova do Imigrante, Mirante da torre de TV, 17.V.1999, fl., G. Hatschbach et al. 69131 (UPCB); Santa Teresa, Reserva Biológica Augusto Ruschi, 5.IX.2003, fr., J. Rossini \& E. Bausen 538 (MBML, UPCB). Aparecidinha, 16.VII.2004, fl., L. Kollmann 6895 (MBML, UPCB).

Meriania tetramera ocorre nos estados da BA e ES. No PEFG é representada por pequenas populações ocorrentes em poucas localidades em Floresta Ombrófila Densa Montana e Alto-montana. Distingue-se pelos frutos capsulares com sementes piramidais e pelas nervuras suprabasais. Seus estames se destacam por portar estruturas infladas de coloração clara na base das anteras. É citada na lista de espécies ameaçadas de extinção do estado do Espírito Santo (Simonelli \& Fraga 2007) como Vulnerável.

17. Miconia chartacea Triana, Trans. Linn. Soc. London 28(1): 119. 1871.

Fig. 2i-k

Arbusto 1,5 m alt. a árvore $7 \mathrm{~m}$ alt.; ramos sub-cilíndricos, achatados ou cilíndricos, densamente revestidos por tricomas lepidotos, as partes mais velhas glabras. Folhas com pecíolo 1-2,5 cm compr.; lâmina 4,5-21,5 × 1-4,5 cm, lanceolada a oblongolanceolada, base decurrente ou cuneada a obtusa, margem inteira, ápice agudo, face adaxial glabra, somente as nervuras revestidas por tricomas lepidotos, face abaxial densamente revestida por tricomas lepidotos, nervuras $3+2$, suprabasais. Panícula com flores agrupadas em glomérulos 8,5-17,5 cm compr., terminal. Flores 5-meras; hipanto 1,6-2,6 mm compr., campanulado, densamente revestido por tricomas lepidotos; cálice duplo, caduco; lacínias internas não claramente diferenciadas, as externas triangulares; pétalas brancas, obovadas, ápice retuso; estames 10 , isomórficos, conectivo prolongado $0,5-1 \mathrm{~mm}$ abaixo das tecas, apêndices ventrais, formados por projeções agudas ou bilobadas; anteras 2-2,5 mm compr., beges, linear-oblongas, ápice arredondado a truncado, poro apical único; ovário $1 / 2$ a $2 / 3$ ínfero, ápice glabro, 2-locular; estilete 4,2-5,1 mm compr., reto, glabro. Baga; sementes 1-2, reniformes.

Material examinado: trilha da Balança, 18.VII.2008, fr., $R$. Goldenberg et al. 1174 (UPCB*); mata do Forninho, 20.V.2010, fr., J. Meirelles et al. 472 (UPCB*).

Material adicional examinado: BRASIL. BAHIA: Catolés-Abaíra, Trilha para o campo do Ouro Fino, 9.II.2006, fl., A.K.A. Santos 783 (UPCB). MINAS GERAIS: Barroso, Mata do Baú, 25.XI.2001, f1., L.C.S. Assis \& M.K. Ladeira 382 (UPCB).

Miconia chartacea ocorre nos estados da BA, GO, DF, MG, ES, SP, RJ, PR, SC. No PEFG é restrita às áreas de Floresta Ombrófila Densa Alto-montana, formando populações muito pequenas. Distingue-se das demais pelas folhas notavelmente discolores, lanceoladas a oblongo-lanceoladas. Difere de $M$. formosa Cogn. pelas folhas mais estreitas com nervuras $3+2$ e pelo ovário glabro.

18. Miconia doriana Cogn., Fl. Bras. 14(4): 376. 1887.

Fig. 21-o

Arbusto ca. $1 \mathrm{~m}$ a árvore ca. $6 \mathrm{~m}$ alt.; ramos cilíndricos, moderadamente revestidos por tricomas estrelados, as partes mais velhas glabras. Folhas com pecíolo 0,3-1,5 cm compr.; lâmina 1,7-10,5 × $0,5-3,7 \mathrm{~cm}$, oval a oval-lanceolada, base atenuada a aguda, margem inteira a levemente ondulada, às vezes repanda, ápice caudado, face adaxial glabra, face abaxial esparsamente revestida por tricomas estrelados a glabra, nervuras $3+2$, suprabasais. Panícula 1,4-8,5 cm compr., terminal. Flores 5-6 meras; hipanto 1,6-2,1 mm compr., campanulado, moderadamente revestido por tricomas estrelados; cálice duplo, caduco; lacínias internas largamente triangulares com ápice arredondado, as externas com ápice agudo ou subulado; pétalas brancas, obovado-oblongas, ápice arredondado a retuso; estames 15-18, isomórficos, conectivo prolongado 0,2-1 $\mathrm{mm}$ abaixo das tecas, apêndices dorsais, agudos; anteras 0,8-2,2 $\mathrm{mm}$ compr., beges, oblongas, ápice arredondado, poro apical único; ovário todo ínfero, glabro, 2-locular; estilete 4,7-5,8 mm compr., reto, glabro. Baga; sementes $1-3$, arredondadas.

Material examinado: Balança, 13.II.2008, fl. e fr., $L$. Kollmann et al. 10588 (RB, MBML, UPCB); trilha da Balança, 18.VII.2008, fr., R. Goldenberg et al. 1175 (MBML, RB, UPCB); trilha para o Forninho, 21.I.2009, fl. e fr., R. Goldenberg et al. 1278 (MBML, RB, UPCB); entorno do alojamento, 9.IV.2009, fr., A. Amorim et al. 7799 (UPCB*).

Material adicional examinado: BRASIL. MINAS GERAIS: Carandaí, Pedra do Sino Hotel Fazenda, Trilha do Sagui, 9.II.2006, fl., N. F. Mota \& D. Souza 546(UPCB).

Miconia doriana ocorre nos estados da BA, MG, ES, SP, RJ, PR, SC. No PEFG ocorre em Floresta Ombrófila Densa Montana e Altomontana. Difere das demais espécies pelas anteras deiscentes através de um poro apical e pelas folhas com superfície abaxial esparsamente revestida por tricomas estrelados a glabra. Destaca-se também pelos ramos tênues, pelas folhas com o menor comprimento médio entre as espécies de Miconia do PEFG (1,7-10,5 cm), e pela presença de um par de domácias diminutas na base da face abaxial. 
19. Miconia formosa Cogn., Monogr. Phan. 7: 842. 1891.

Fig. $2 \mathrm{p}-\mathrm{t}$

Arbusto ca. $4 \mathrm{~m}$ alt. a árvore ca. $14 \mathrm{~m}$ alt.; ramos sub-cilíndricos a quadrangulares arredondados, às vezes compressos, revestidos por tricomas lepidotos muito adpressos. Folhas com pecíolo 1,5-8 cm compr.; lâmina 7,2-21,5 × $2-7,5 \mathrm{~cm}$, elíptico-lanceolada a oblongo-elíptica, base atenuada, aguda ou levemente decurrente, margem inteira a levemente ondulada, às vezes repanda, ápice acuminado a cuneado, face adaxial glabra, revestida moderadamente por tricomas lepidotos principalmente sobre as nervuras, às vezes com tricomas estrelados esparsos, face abaxial densamente revestida por tricomas estrelado lepidotos, nervuras $5+2$, basais a suprabasais. Panículas com flores agrupadas em glomérulos 3,5-12 cm compr., terminal. Flores 5-6 meras; hipanto 2,4-2,9 mm compr., oblongo a campanulado, densamente revestido por tricomas lepidotos; cálice duplo, caduco; lacínias internas não claramente diferenciadas, as externas formadas por dentículos; pétalas brancas, obovadas, ápice retuso; estames 10-12, dimórficos, conectivo prolongado ca. $0,1 \mathrm{~mm}$ compr., apêndices dorsais, lobados, anteras 2,3-2,8 mm compr., amarelas in sicco, oblongas, ápice truncado, poro apical único; ovário $2 / 3$ a $1 \frac{1}{2}$ ínfero, ápice esparsamente revestido por tricomas estrelados, 3-locular; estilete linear, 2,1-2,9 mm compr., glabro. Fruto baga; sementes $5-8$, arredondadas.

Material examinado: trilha para o Forninho, 17.VII.2008, fl., R. Goldenberg et al. 1162 (RB, MBML, UPCB); trilha da Balança, fl., 18.VII.2008, R. Goldenberg et al. 1178 (MBML, RB, UPCB); 18.VII.2008, fl., $R$. Goldenberg et al. 1180 (MBML, RB, UPCB); Balança, 13.II.2008, fr., C.N. Fraga et al. 1832 (MBML, RB, UPCB).

Miconia formosa ocorre nos estados de MG, ES, RJ. No PEFG ocorre em Floresta Ombrófila Densa Alto-montana. Assemelha-se a M. chartacea pelas folhas com superfície abaxial densamente revestida por tricomas estrelado lepidotos, porém, difere-se pelas nervuras $5+2$ e pelo ovário esparsamente revestido por tricomas estrelados.

20. Miconia hirtella Cogn., Fl. bras. 14(4): 423. 1888.

Fig. $2 \mathrm{u}-\mathrm{w}$

Arbusto ca. $1 \mathrm{~m}$ a arvoreta ca. $4 \mathrm{~m}$ alt.; ramos cilíndricos, sub-cilíndricos ou quadrangulares arredondados, revestidos por tricomas simples, ásperos, encurvados, estrelado-estipitados e dendríticos de haste longa, as partes mais velhas glabras. Folhas com pecíolo $0,2-1,9 \mathrm{~cm}$ compr.; lâmina 3,6-14 × 1,1-4,5 cm, oblongo-lanceolada, base aguda a arredondada, margem levemente serreada ou denticulada, ápice agudo ou acuminado, face adaxial moderadamente revestida por tricomas simples prostrados a glabra, face abaxial esparsamente revestida por tricomas simples e estrelado-estipitados, nervuras $3+2$, basais. Panícula com flores agrupadas em glomérulos 3,2-9,5 cm compr., terminal. Flores 5-meras; hipanto 1,2-1,6 mm compr., urceolado, esparsamente revestido por tricomas estrelado estipitados a glabro; cálice duplo, persistente; lacínias internas largamente triangulares, as externas formadas por dentículos; pétalas brancas, obovadas, ápice retuso a arredondado; estames 10, subisomórficos ou levemente dimórficos, conectivo prolongado $0,5-0,7$ $\mathrm{mm}$ abaixo das tecas, apêndices ventrais e dorsais, ventrais bilobados, dorsais sem forma definida; anteras $0,7-1 \mathrm{~mm}$ compr., beges in sicco, oblongas, ápice truncado, 4 poros apicais; ovário $1 / 2$ ínfero, glabro, 2-4 locular; estilete 2,3-2,9 mm compr., reto, glabro. Baga; sementes numerosas, ovais.

Material examinado: s. 1., 12.X.2000, fl., L. Kollmann \& C.N. Fraga 3143 (MBML, UPCB); 27.I.2004, fr., L. Kollmann 6393 (MBML, UPCB); 30.X.2004, fr., $L$. Kollmann et al. 7190 (MBML, UPCB); trilha na mata para o Forninho, 14.X.2008, fl., C.N. Fraga et al. 2225 (MBML, RB, UPCB); brejo próximo à sede do parque, 20.I.2009, fr., R. Goldenberg 1271 (MBML, RB, UPCB); floresta a esquerda da trilha da piscina ao Mirante, 8.IV.2009, fr., J. Meirelles et al. 293 (UPCB*).

Miconia hirtella ocorre nos estados da BA, GO, DF, MG, ES. No PEFG é comum e abundante próximo a córregos em Floresta Ombrófila Densa Montana e Alto-montana, especialmente nas áreas úmidas e bordas de mata. Caracteriza-se pelas anteras deiscentes por quatro poros apicais e pelos ramos e folhas revestidos por tricomas simples.

21. Miconia kriegeriana Baumgratz \& Chiavegatto, Acta Bot. Brasil. 20(2): 484. $2006 . \quad$ Fig. 2x-aa

Arbusto ca. $2 \mathrm{~m}$ a árvore ca. $6 \mathrm{~m}$ alt.; ramos sub-cilíndricos a cilíndricos, densamente revestidos por tricomas estrelados longo-ramificados nos nós, as partes mais velha glabras. Folhas com pecíolo 0,3-1,7 cm compr.; lâmina 3,3-11,5 × 1,1-4,6 $\mathrm{cm}$, elíptico-oblonga a lanceolada, base aguda a arredondada, margem inteira a curto-serreada, ápice acuminado, face adaxial moderadamente revestida por tricomas estrelados a glabra, face abaxial esparsamente a moderadamente revestida por tricomas estrelados, nervuras $3+2$, basais. Panícula $2-10 \mathrm{~cm}$ compr., terminal. Flores 5-meras; hipanto 2,2-2,5 mm compr., campanulado a oblongo, 
densamente revestido por tricomas estrelados; cálice duplo, persistente; lacínias internas não diferenciadas ou largamente triangulares, as externas triangulares; pétalas brancas, obovadas, ápice arredondado a retuso; estames 12-15, dimórficos, alternando entre apêndices maiores e menores, conectivo prolongado 0,9-1,4 mm abaixo das tecas, apêndices ventrais bilobados; anteras 1,4-2,6 cm compr., pardacentas, oblongas, ápice arredondado ou retuso, poro apical único; ovário 1/2 ínfero, glabro, 3-locular; estilete 3,7-6,8 mm compr., reto, glabro. Baga; sementes 20 a numerosas, piramidal-arredondadas.

Material examinado: 27.I.2004, fl., L. Kollmann 6378 (MBML, UPCB); trilha para as Piscinas, 12.II.2008, fl., A.P. Fontana et al. 4813 (UPCB*); 2.V.2008, fr., $R$. Goldenberg et al. 1057 (RB, UPCB); 21.I.2009, fl., $R$. Goldenberg et al. 1280 (UPCB*); brejo próximo a sede do Parque, 20.I.2009, fl. e fr., R. Goldenberg et al. 1268 (UPCB*); entre as Piscinas e o Mirante, 7.IV.2009, fr., J. Meirelles et al. 282 (UPCB*); arredores das Piscinas, 18.V.2010, fr., J. Meirelles et al. 444 (UPCB*); trilha para o Forninho, 20.V.2010, fl. e fr., J. Meirelles et al 458 (UPCB*).

Miconia kriegeriana ocorre nos estados de MG, ES. No PEFG é representada por populações médias ocorrentes em Floresta Ombrófila Densa Montana e Alto-montana em ambientes úmidos próximos a córregos. Miconia kriegeriana distingue-se das demais espécies de Miconia pelas panículas com ramos escorpióides.

22. Miconia latecrenata (DC.) Naudin, Ann. Sci. Nat., Bot., ser. 3, 16: 239. 1851 Fig. 2ab

Arbusto a arvoreta 3-6 $\mathrm{m}$ alt.; ramos cilíndricos, densamente revestidos por tricomas estrelados. Folhas com pecíolo 0,6-2,2 cm compr.; lâmina 8,1-16 ×2,2-5 cm, oval oblonga, base aguda, margem ondulada a denteada, ápice acuminado, face adaxial glabra, às vezes moderadamente revestida por tricomas estrelados, face abaxial moderadamente revestida por tricomas estrelados, nervuras 3+2, basais. Panícula 4,5-13,5 cm compr., lateral e terminal. Flores 5-meras; hipanto 1,1-1,6 mm compr., campanulado, densamente revestido por tricomas estrelados; cálice duplo, persistente; lacínias internas largamente triangulares, as externas formadas por dentículos; pétalas brancas, obovadas, ápice retuso; estames 10, isomórficos, conectivo prolongado $0,4-0,5 \mathrm{~mm}$ abaixo das tecas, apêndices representados por um cálcar dorsal e dois ventrais curtos e arredondados, anteras 0,8-0,9 mm compr., brancas, oblongo-obovadas em vista ventral, ápice arredondado ou retuso, deiscentes por dois poros apicais ventralmente inclinados, semelhante a rimas; ovário ínfero, glabro, 3-locular; estilete 3,5-3,6 mm compr., reto, glabro. Baga; sementes 15 a numerosas, ovais.

Material examinado: s. 1., 9.IV.2004, fl., L. Kollmann \& R.L. Kollmann 6611 (MBML, UPCB); trilha para as Piscinas, 19.VII.2007, fr., L. Kollmann et al. 9986 (MBML, UPCB); 2.V.2008, fl., R. Goldenberg et al. 1064 (RB, UPCB); estrada entre Balança e rio Manso, 16.X.2008, fr., C.N. Fraga et al. 2260 (UPCB*); arredores da gruta da Santinha, fr., 18.V.2010, J. Meirelles et al. 445 (MBML, RB,UPCB); trilha da Balança, 21.V.2010, fl., J. Meirelles et al. 481 (MBML, RB, UPCB).

Miconia latecrenata ocorre nos estados da BA, MG, ES, SP, RJ, PR, SC, RS. No PEFG ocorre em Floresta Ombrófila Densa Montana e Alto-montana. Distingue-se das demais espécies de Miconia do PEFG pelas inflorescências laterais e terminais e pelas anteras deiscentes por poros ventralmente inclinados, semelhantes à rimas.

23. Miconia octopetala Cogn., Monogr. Phan. 7: 754. 1891.

Fig. 2ac-ad

Arvoreta a árvore 8-16 m alt.; ramos subcilíndricos a compressos, densamente revestidos por tricomas dendríticos longos, com ramificações curtas. Folhas com pecíolo 1,1-5 cm compr.; lâmina 10-27 ×6-15 cm, oblonga a elíptico-oblonga, base arredondada a cuneada, margem inteira, às vezes repanda ou curto-denteada, ápice acuminado a retuso, face adaxial moderadamente revestida por tricomas dendríticos, caducos, face abaxial densamente revestida por tricomas dendríticos mais curtos que os da face adaxial, nervuras $3+2$ a $5+2$, basais a suprabasais. Panícula de glomérulos 3-10 cm compr., terminal. Flores 8-meras; hipanto 3,2-4 mm compr., campanulado, densamente revestido por tricomas dendríticos, curto-ramificados; cálice duplo, caduco; lacínias internas não claramente diferenciadas, as externas formadas por dentículos; pétalas brancas, linear-obtriangulares, ápice retuso; estames 16, isomórficos, conectivo não prolongado abaixo das tecas, apêndices ventrais, bilobados; anteras 3,6-5,3 mm compr., beges in sicco, oblongas, ápice arredondado, poro apical único; ovário 1/2 ínfero a ínfero, glabro, 3-4-locular; estilete 6-8,4 $\mathrm{mm}$ compr., reto ou curvo, glabro. Baga; sementes 12 a numerosas, ovais a ovais alongadas.

Material examinado: trilha da Balança, 18.VII.2008, fl., R. Goldenberg et al. 1176 (RB, MBML, UPCB); arredores do alojamento, mata do Klaus, 21.V.2010, fl., J. Meirelles et al. 487 (UPCB*). 
Material adicional examinado: BRASIL. ESPÍRITO SANTO: Santa Teresa, Nova Lombardia, Reserva Biológica Augusto Ruschi, 19.IX.2002, fl., R. R. Vervloet et al. 1013 (MBML, UPCB). Reserva Biológica Augusto Ruschi, 19.VIII.2003, fl., J. Rossini et al. 478 (MBML, UPCB). São Lourenço, Mata Fria, Terreno de Clério Loss, 9.IX.1998, fr., L. Kollmann et al. 488 (MBML, UPCB).

Miconia octopetala ocorre nos estados da BA, ES, RJ. No PEFG tem ocorrência restrita a poucas localidades de Floresta Ombrófila Densa Montana e Alto-montana onde é representada por poucos indivíduos. Distingue-se pelas flores 8-meras e robustas em comparação as demais espécies de Miconia do PEFG. É citada na lista de espécies ameaçadas de extinção do estado do Espírito Santo (Simonelli \& Fraga 2007) como Vulnerável.

24. Miconia pusilliflora (DC.) Naudin, Ann. Sci. Nat., Bot., sér. 3, 16: 171. 1851. Fig. 3a-b

Arvoreta ca. $2 \mathrm{~m}$ alt. a árvore ca. $7 \mathrm{~m}$ alt.; ramos cilíndricos a sub-cilíndricos, densamente revestidos por tricomas estrelados, as partes mais velhas glabras. Folhas com pecíolo $0,3-1,8 \mathrm{~cm}$ compr.; lâmina 4,2-12,6 × 1-4 cm, elíptico-oblonga a lanceolada, base atenuada a cuneada, margem inteira a denticulada, ápice caudado, face adaxial glabra, face abaxial moderadamente a esparsamente revestida por tricomas estrelados, nervuras $3+2$, basais. Panícula 4,5-11,5 cm compr., terminal. Flores 4-5-meras; hipanto 1,5-2 mm compr., campanulado, densamente revestido por tricomas estrelados; cálice duplo, caduco; lacínias internas largamente triangulares, as externas formadas por dentículos; pétalas brancas, obovadas, ápice arredondado; estames 8-10, isomórficos, conectivo prolongado ca. $0,1 \mathrm{~mm}$ abaixo das tecas, inapendiculado, anteras 1,4-2 mm compr., brancas, oblongas, ápice retuso, longitudinal, abrindo-se por poros ventralmente inclinados semelhante à rimas, do ápice a base da tecas; ovário $2 / 3$ ínfero, revestido por tricomas estrelados, 3-locular; estilete 2,9-3,9 mm compr., reto, glabro. Baga; sementes 2-3, hemisféricas.

Material examinado: 10.IV.2004, fl., L. Kollmann \& R.L. Kollmann 6643 (RB, MBML, UPCB); 9.IV.2009, fl., L. Kollmann et al. 11512 (UPCB*); capoeira atrás do Mirante, 7.IV.2009, fl., R. Goldenberg et al. 1413 (MBML, RB, UPCB); rio Manso, 19.V.2010, fl., J. Meirelles et al. 447 (UPCB*); Forninho, 20.V.2010, fr., J. Meirelles et al. 466 (UPCB*).

Material adicional examinado: BRASIL. ESPÍRITO SANTO: Castelo, Caxixe Quente, 3.V.2008, fl., $R$. Goldenberg et al. 1083 (UPCB). MINAS GERAIS: Barroso, Mata do Baú, 25.XI.2001, fr., L.C.S. Assis \& M.K. Ladeira 383 (UPCB).
Miconia pusilliflora ocorre nos estados da BA, MG, ES, SP, RJ, PR, SC, RS. Também ocorre na Argentina e Paraguai (Wurdack 1962). No PEFG é relativamente comum e ocorre em Floresta Ombrófila Densa Montana e Alto-montana representada por populações de poucos indivíduos. Assemelha-se a $M$. sellowiana Naudin pelas anteras deiscentes através de poros ventralmente inclinados, porém difere-se pelas folhas com nervuras basais e pelo ovário revestido por tricomas estrelados.

25. Miconia saldanhaei Cogn. in Mart., Fl. bras. 14(4): 372.1887.

Fig. 3c-e

Arbusto ca. $2 \mathrm{~m}$ alt. a arvoreta ca. $5 \mathrm{~m}$ alt.; ramos quadrangulares ou compressos, densamente revestidos por tricomas estrelados e dendríticos com a base alargada. Folhas com pecíolo 0,5-3,7 cm compr.; lâmina 5,1-27 × 3-11,5 cm, oblongolanceolada, elíptico-oblonga ou obovada, base atenuada a cuneada, às vezes arredondada, margem inteira a denticulada, ápice acuminado a caudado, face adaxial densamente revestida por tricomas estrelados de ramos longos a glabras, face abaxial moderadamente a densamente revestida por tricomas dendríticos, nervuras $3+2$ a $5+2$, basais a suprabasais. Panículas com flores agrupadas em glomérulos 10 $25 \mathrm{~cm}$ compr., terminais. Flores 5-6-meras; hipanto 1,6-2 mm compr., campanulado, moderadamente a densamente revestido por tricomas estrelados e dendríticos; cálice duplo, persistente; lacínias internas largamente triangulares, as externas em forma de dentículos; pétalas brancas, obovadas, ápice retuso; estames 10, isomórficos, conectivo prolongado ca. $0,7 \mathrm{~mm}$ abaixo das tecas, inapendiculado, anteras 1-1,3 mm compr., brancas, oblongas, ápice truncado, poro apical único; ovário ínfero, revestido por tricomas simples, longos, 3-locular; estilete 3,4-4,2 mm compr., reto, glabro. Baga; sementes 4-12, ovais, hemisféricas ou amorfas.

Material examinado: 12.VI.2004, fr., L. Kollmann \& R.L. Kollmann 6741 (MBML, UPCB); 25.III.2005, fr., L. Kollmann et al. 7547 (MBML, UPCB); trilha para o Forninho, 12.II.2008, fr., P. Labiak et al. 4569 (UPCB); trilha para as Piscinas, 2.V.2008, fr., R. Goldenberg et al. 1054, (UPCB); brejo próximo à sede do Parque, 20.I.2009, fr., R. Goldenberg et al. 1273 (UPCB*); atrás do Mirante, 7.IV.2009, fr., J. Meirelles et al. 292 (UPCB*); 9.IV.2009, fr., L. Kollmann et al. 11507 (UPCB*); rio Manso, 19.V.2010, fr., J. Meirelles et al. 454 (MBML, RB); 20.V.2010, fr., J. Meirelles et al. 459 (MBML, RB). Material adicional examinado: BRASIL. ESPÍRITO SANTO: Santa Teresa, São Lourenço, 2.XII.1998, f1., L. Kollmann et al. 1182 (MBML, UPCB). 

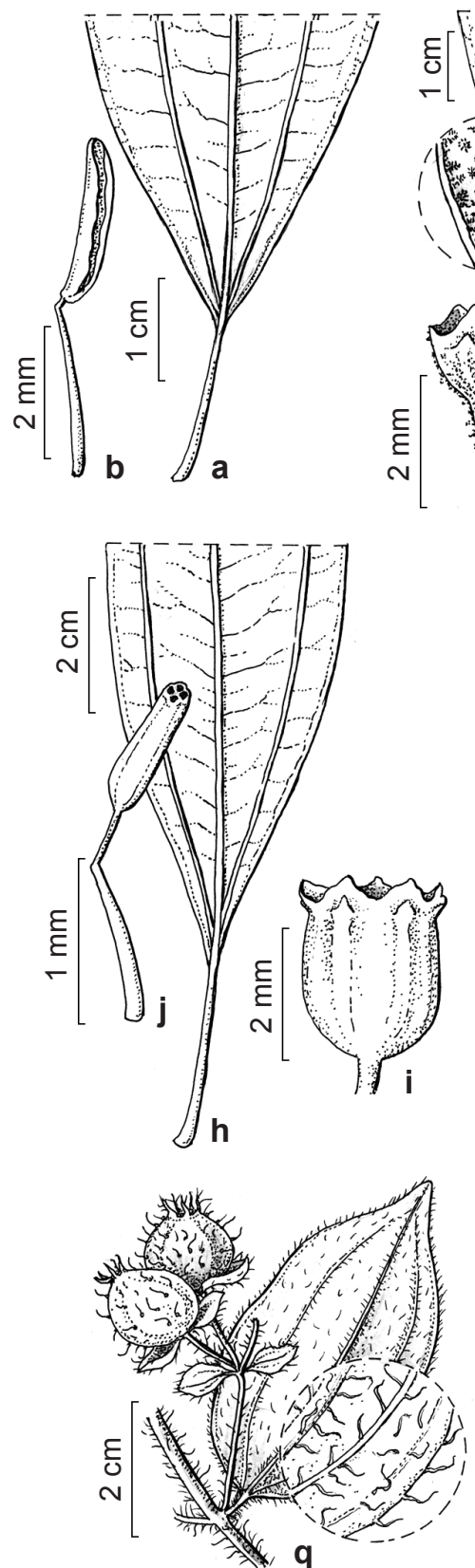
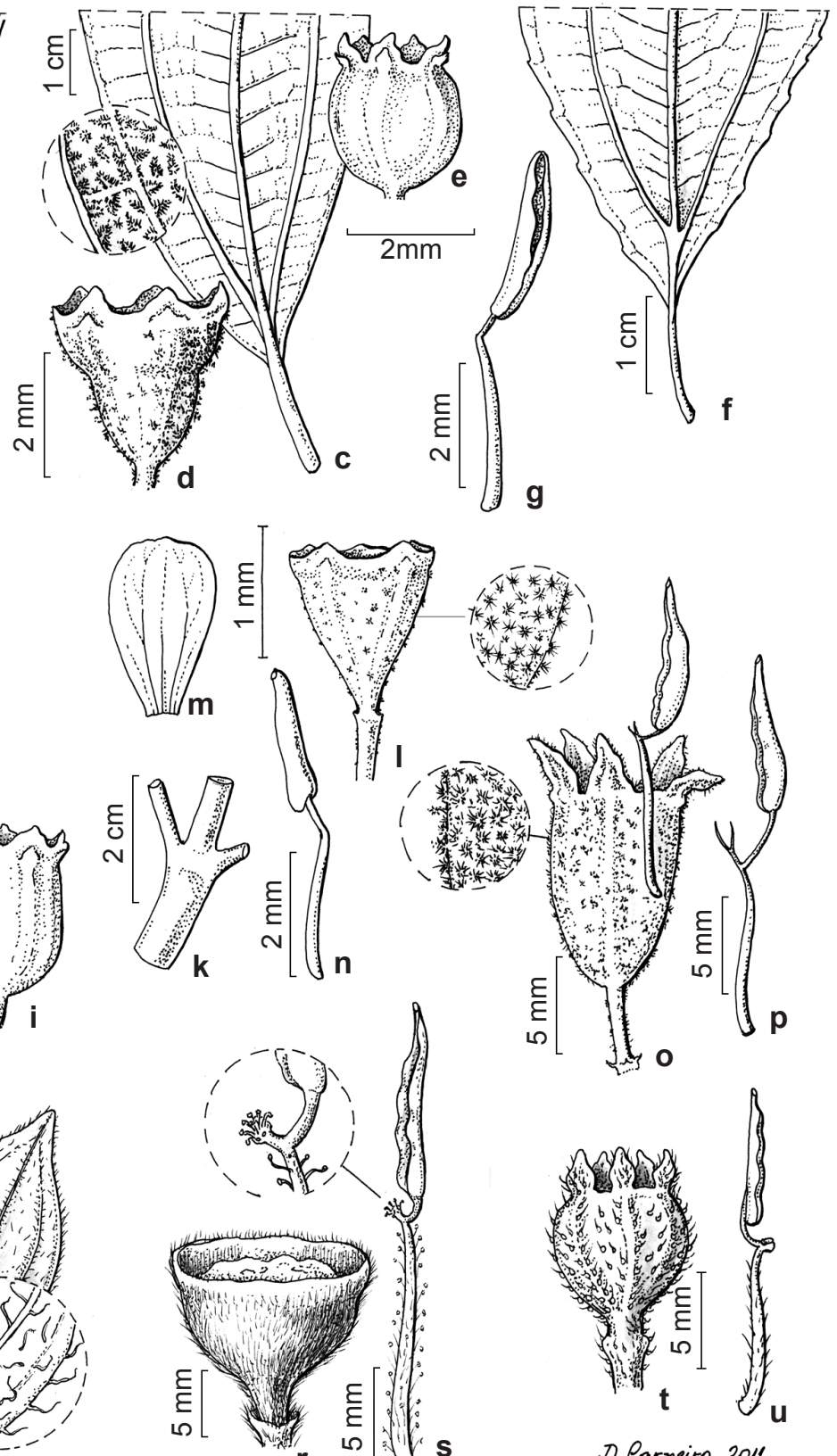

Figura 3 - a-b. Miconia pusilliflora - a. folha; b. estame (Meirelles et al. 447). c-e. M. saldanhae - c. folha com detalhe do indumento; d. hipanto; e. fruto (Goldenberg 1054). f-g. M. sellowiana - f. folha; g. estame (Kollmann et al. 852). h-j. M. theaezans - h. folha; i. hipanto; j. estame (Kollmann 6428). k-n. M. tristis - k. ramo; 1. hipanto com detalhe do indumento; m. pétala; n. estame (Meirelles et al. 476). o-p. Microlepis oleifolia - o. hipanto com detalhe de indumento; p. estames (Meirelles et al. 295). q. Pleiochiton blepharodes - q. ramo, face abaxial da folha com detalhe do indumento e frutos (Meirelles et al. 299). r-s. Tibouchina arborea - r. hipanto; s. estame com detalhe do indumento no conectivo (Kollmann et al. 11511). t-u. T. castellensis - t. hipanto; u. estame (Meirelles et al. 291).

Figure 3 - a-b. Miconia pusilliflora - a. leaf; b. stamen (Meirelles et al. 447). c-e. M. saldanhae - c. leaf with detail of indument; d. hypanthium; e.fruit (Goldenberg 1054). f-g. M. sellowiana - f. leaf; g. stamen (Kollmann et al. 852). h-j. M. theaezans - h. leaf; i. hypanthium; j. stamen (Kollmann 6428). k-n. M. tristis - k. branch; 1. hypanthium with detail of indument; m. petal; $\mathrm{n}$. stamen (Meirelles et al. 476). o-p. Microlepis oleifolia - o. hypanthium with detail of indument; p. stamens (Meirelles et al. 295). q. Pleiochiton blepharodes - q. branch, abaxial surface of the leaf with detail of indument and fruits (Meirelles et al. 299). r-s. Tibouchina arborea - r. hypanthium; s. stamen with detail of indument in the connective (Kollmann et al. 11511). t-u T. castellensis - t. hypanthium; u. stamen (Meirelles et al. 291). 
Miconia saldanhae ocorre nos estados do ES e RJ. No PEFG é comum, ocorrendo nas bordas da Floresta Ombrófila Densa Montana e Altomontana. Difere de M. kriegeriana pelas folhas com superfície abaxial revestida por tricomas dendríticos, consideravelmente maiores e pelas lacínias externas em forma de dentículos.

26. Miconia sellowiana Naudin, Ann. Sci. Nat., Bot., ser. 3, 16: 206. 1851. Fig. 3f-g

Arvoreta a árvore 6-8 $\mathrm{m}$ alt.; ramos cilíndricos, densamente revestidos por tricomas estrelados, as partes mais velhas glabras. Folhas com pecíolo 0,3-1,1 cm compr.; lâmina 3,3-16,3 × 0,5-3,5 cm, lanceolada a oblongo-lanceolada, base atenuada a decurrente, margem inteira a serreada, ápice caudado, ambas as faces moderadamente revestidas por tricomas estrelados a glabras, nervuras $3+2$, suprabasais. Panícula 3,5-10,5 cm compr., terminal. Flores 5-meras; hipanto 1,1-1,2 mm compr., campanulado, moderadamente revestido por tricomas estrelados; cálice duplo, caduco; lacínias internas largo-triangulares, as externas formadas por dentículos; pétalas brancas, obovadas, ápice arredondado; estames 10, isomórficos, conectivo prolongado $0,1-0,4 \mathrm{~mm}$ abaixo das tecas, apêndices levemente bilobados, ventrais, anteras 1,2-1,6 mm compr., brancas, oblongas, ápice truncado, dois poros apicais amplos, ventralmente inclinados atingindo $1 / 2$ $\mathrm{a}^{2} / 3$ do compr. total da antera; ovário $1 / 2$ ínfero, glabro, 3-locular; estilete 2,3-2,9 mm compr., reto, glabro. Baga; sementes 13-19, piramidais.

Material examinado: 27.I.2004, fr., L. Kollmann et al. 6388 (RB, UPCB); trilha para as piscinas, 2.V.2008, fr., R. Goldenberg et al. 1055 (RB, UPCB).

Material adicional examinado: BRASIL. ESPÍRITO SANTO: Santa Teresa, Santo Antônio, 29.X.1998, fl., L. Kollmann et al. 852 (UPCB). PARANÁ: Curitiba, Jardim Botânico, 10.IX.2004, fl., F.B. Matos et al. 40 (UPCB).

Miconia sellowiana ocorre nos estados de GO, DF, MG, ES, SP, RJ, PR, SC, RS. No PEFG ocorre em Floresta Ombrófila Densa Montana sendo relativamente comum nas trilhas. Difere de $M$. pusilliflora pelas folhas com nervuras suprabasais e pelo ovário glabro. Ver também comentários em M. pusilliflora.

27. Miconia theaezans (Bonpl.) Cogn., Fl. bras. 14(4): 419. 1888.

Fig. $3 h-j$

Arbusto a arvoreta ca. $2 \mathrm{~m}$ alt.; ramos subcilíndricos, glabros. Folhas com pecíolo 0,5-2,3 cm compr.; lâmina 2,7-14,5 × 1-3,3 cm, oblongolanceolada a obovado-oblonga, base atenuada a aguda, margem inteira a levemente serreada, ápice curto-acuminado a acuminado, ambas as faces glabras, nervuras 3 a 3+2, basais. Panícula 7-12,5 cm compr., terminal. Flores 5-meras; hipanto 1,11,6 mm compr., campanulado, glabro; cálice duplo, persistente; lacínias internas arredondadas e róseas, as externas formadas por dentículos; pétalas brancas, arredondadas, ápice arredondado a retuso; estames 10 , isomórficos, conectivo prolongado $0,2-0,3$ $\mathrm{mm}$ compr. abaixo das tecas, apêndices ventrais, levemente bituberculados, anteras $0,9-1,1 \mathrm{~mm}$ compr., brancas, oblongas, ápice truncado, deiscente por 4 poros apicais; ovário $1 / 2$ ínfero, glabro, 3-locular; estilete 2-3 mm compr., reto, glabro. Baga; sementes numerosas, oval-arredondadas.

Material examinado: 28.I.2004, fl., L. Kollmann 6428 (MBML, UPCB); 28.IV.2006, fr., L. Kollmann \& R.L. Kollmann 8884 (MBML, UPCB); trilha para as piscinas. 7.IV.2009, fr., J. Meirelles et al. 284 (CEPEC, MBML, $\mathrm{RB}, \mathrm{UPCB})$.

Miconia theaezans ocorre nos estados da BA, GO, DF, MG, ES, SP, RJ, PR, SC. Também ocorre na Venezuela (Wurdack 1973), Equador (Wurdack 1980) e Guianas (Wurdack et al. 1993). No PEFG ocorre abundantemente em Floresta Ombrófila Densa Montana. Assemelha-se a M. hirtella pelas anteras deiscentes por quatro poros apicais, diferindo-se pelas folhas com superfície abaxial glabra e pelo hipanto campanulado.

28. Miconia tristis Spring, Flora 20, Beibl. 2: 76.1837 . Fig. 3k-n

Arbusto a arvoreta $2-5 \mathrm{~m}$ alt.; ramos cilíndricos glabros. Folhas com pecíolo $0,2-1,4 \mathrm{~cm}$ compr.; lâmina 2,3-12,5 × 0,5-2,5 cm, elíptico-lanceolada, base atenuada, margem inteira, crenulada, levemente serreada próximo ao ápice, ápice acuminado a caudado, face adaxial moderadamente revestida por tricomas estrelados a glabras, face abaxial glabra, nervuras $3+2$, basais. Panícula 1,3-7,5 cm compr., terminais e laterais. Flores 5-6-meras; hipanto 1-2,1 mm compr., campanulado, moderadamente revestido por tricomas estrelados; cálice duplo, caduco; lacínias internas largo-triangulares, as externas formadas por dentículos; pétalas brancas a arroxeadas, obovado-oblongas, ápice retuso a arredondado; estames 10-12, levemente dimórficos, conectivo prolongado $0,2-0,4 \mathrm{~mm}$ abaixo das tecas, apêndices dorsais agudos e ventrais bilobados, às vezes ausentes, anteras 1,6-2,8 $\mathrm{mm}$ compr., brancas, oblongas, ápice arredondado, poro apical único; ovário 1/2 ínfero, glabro, 3-locular; estilete 3,2-4,6 mm compr., reto, glabro. Baga; sementes 4-6, hemisféricas. 
Material examinado: 12.X.2000, fr., L. Kollmann \& C.N. Fraga 3135 (MBML, UPCB); 9.IV.2004, fl., L. Kollmann \& R.L. Kollmann 6633 (MBML, UPCB); 11.VII.2005, fl. e fr., L. Kollmann \& R.L. Kollmann 7967 (MBML, UPCB); 29.IV.2006, fl., L. Kollmann \& R.L. Kollmann 8906 (MBML, UPCB); trilha para as Piscinas, 2.V.2008, fr., R. Goldenberg et al. 1050 (UPCB); entorno do alojamento, 9.IV.2009, fl., A. Amorim et al. 7828 (UPCB*); atrás do Mirante, 7.IV.2009, fl., J. Meirelles et al. 288 (UPCB*); Rio Manso, 19.V.2010, fr., J. Meirelles et al. 448 (UPCB*); trilha da Balança, 21.V.2010, fl e fr., J. Meirelles et al. 476 (UPCB*).

Miconia tristis ocorre nos estados da BA, MG, ES, SP, RJ, PR, SC. No PEFG ocorre em praticamente todos os tipos de vegetação sendo a espécie de Melastomataceae mais bem distribuída e com o maior número de indivíduos observados em campo. Distingue-se pelas inflorescências terminais e laterais, diferindo de $M$. latecrenata pelas anteras deiscentes por poro apical único.

29. Microlepis oleifolia (DC.) Triana, Trans. Linn. Soc. London 28(1): 36, t. 2, f. 25. 1871 Fig. 3o-p

Arbusto 1,5-2 m alt.; ramos cilíndricos a subcilíndricos, revestidos por tricomas dendríticos e estrelados. Folhas com pecíolo $0,5-1,5 \mathrm{~cm}$ compr.; lâmina 4-10 × 1-3 cm, lanceolada, base aguda a arredondada, margem inteira, ápice agudo a arredondado, face adaxial moderadamente revestida por tricomas estrelados, face abaxial densamente revestida por tricomas estrelados sobre toda a lâmina e tricomas dendríticos sobre a nervura central, nervuras 5+2, basais. Panícula 8-20 cm compr., terminal, às vezes com ramos adicionais. Flores 5-meras; hipanto 4,5-6,5 mm compr., oblongo, densamente revestido por tricomas estrelados; cálice simples, caduco; lacínias triangulares, ovais, ou triangulares alongadas; pétalas lilases às vezes com base esbranquiçada, obovadas a obovado-oblongas, ápice retuso a arredondado; estames 10, dimórficos, conectivo prolongado $0,2-3 \mathrm{~mm}$ abaixo das tecas, apêndices ventrais, bífidos, anteras $0,5-1 \mathrm{~cm}$ compr., purpúreas, subuladas, ápice arredondado, poro apical único; ovário $1 / 2$ súpero, revestido por tricomas simples, 5-locular; estilete 7-9,5 mm compr., curvo, glabro. Cápsula; sementes numerosas, cocleadas.

Material examinado: trilha para o Forninho, 12.II.2008, fl., P. Labiak et al. 4568 (RB, UPCB, MBML); brejo próximo à sede do Parque, 1.V.2008, fr., R. Goldenberg et al. 1036 (RB, UPCB, MBML); entre as Piscinas e o Mirante, 7.IV.2009, fr., J. Meirelles et al. 281 (UPCB*); 8.IV.2009, fl., R. Goldenberg et al.1419 (UPCB*); floresta à esquerda da trilha das Piscinas ao Mirante, 8.IV.2009, fl. J. Meirelles et al. 295 (UPCB*).
Microlepis oleifolia ocorre nos estados de MG, ES, SP, RJ. No PEFG ocorre em áreas abertas de solo úmido em Floresta Ombrófila Densa Montana e Alto-montana. Distingue-se das demais espécies com cápsulas pela presença de tricomas estrelados no hipanto.

30. Pleiochiton blepharodes (DC.) Reginato, R. Goldenb. \& Baumgratz, Rodriguésia 61(1): 116. 2010.

Fig. $3 q$

Epífita $30-50 \mathrm{~cm}$ alt.; ramos cilíndricos, moderado a densamente revestidos por tricomas simples, eglandulosos Folhas com pecíolo 0,3-1,7 cm compr., lâmina 3-8 $\times 1,5-5 \mathrm{~cm}$, elípticas a ovais, base obtusa a arredondada, margem inteira, ápice acuminado, ambas as faces esparso a moderadamente revestidas por tricomas simples, eglandulosos, nervuras 5 ou $3+2$, basais. Cimeira 2-9 cm compr., lateral. Flores (5)6-meras; hipanto ca. 4,2 mm compr., campanulado, esparsamente revestido por tricomas simples, glandulares; cálice duplo, persistente; lacínias internas largotriangulares, as externas lineares; pétalas brancas, oblongas a obovadas, ápice arredondado a acuminado; estames (10)12, levemente dimórficos, conectivo não prolongado abaixo das tecas, apêndices dorsais inconspícuos bilobados, anteras 3-3,5 mm compr., amarelas in sicco, oblongas, ápice arredondado, poro apical único; ovário $1 / 2$ ínfero, revestido por tricomas glandulares, 3-locular, estilete ca. $7 \mathrm{~mm}$ compr., curvo, glabro. Baga; sementes numerosas, ovais a alongadas.

Material examinado: Fazenda Forno Grande, 28.I.2004, fl. e fr., L. Kollmann 6420 (MBML, UPCB); trilha para o Forninho, 12.II.2008, fl., L. Kollmann et al. 10558 (RB); brejo próximo a sede do Parque, 1.V.2008, fr., $R$. Goldenberg et al. 1032 (UPCB); entorno do alojamento, 9.IV.2009, fr., A. Amorim et al. 7805 (RB, UPCB); vale ao lado do pasto, à direita da entrada, 9.IV.2009, fr., $J$. Meirelles et al. 299 (CEPEC, MBML, UPCB).

Pleiochiton blepharodes ocorre nos estados da BA, MG, ES, SP, RJ, PR, SC. No PEFG é representado por poucos indivíduos que ocorrem em Floresta Ombrófila Densa Montana e Alto-montana em locais úmidos e sombreados. Caracteriza-se pelo hábito epifítico, pelos ramos e folhas revestidos por tricomas simples e pelos frutos do tipo baga, além das brácteas e bractéolas avermelhadas, vistosas.

31. Tibouchina arborea (Gardner) Cogn., Fl. bras. 14(3): 299. 1855.

Fig. 3r-s

Arvoreta a árvore 6-12 $\mathrm{m}$ alt.; ramos cilíndricos, esparsamente revestidos por tricomas simples, dendríticos e estrelados. Folhas com 
pecíolo $1-3,4$ cm compr.; lâmina 3,7-9,7 × 1-4,3 $\mathrm{cm}$, oval, oblonga ou oval-oblonga, base atenuada a arredondada, margem inteira, ápice acuminado, ambas as faces moderadamente revestidas por tricomas dendríticos adpressos, nervuras 5, basais. Flores solitárias, terminais, 5-meras; hipanto ca. 7,2 mm compr., campanulado, densamente revestido por tricomas simples; cálice simples, caduco; lacínias oblongas; pétalas de coloração mutável de lilás claro com base branca a brancas com a base vermelha, obovadas, ápice retuso; estames 10, dimórficos, filetes inteiramente revestidos por tricomas glandulares, conectivo dos estames menores prolongado $0,7-1 \mathrm{~mm}$ abaixo das tecas, dos estames maiores $0,7-1,2 \mathrm{~mm}$ abaixo das tecas, apêndices ventrais, nos estames menores e nos maiores densamente revestidos por tricomas glandulares, anteras menores $8,8-11,2 \mathrm{~mm}$ compr., maiores 1-1,2 cm compr., amarelas in sicco, subuladas, ápice arredondado, poro apical único; ovário $1 / 2$ súpero, densamente revestido por tricomas simples, 5-locular; estilete 2,3-2,5 cm compr., curvo, $2 / 3$ de seu comprimento densamente revestido por tricomas dendríticos. Cápsula; sementes numerosas, cocleadas alongadas.

Material examinado: Balança, 18.VII.2008, fr., A.P. Fontana et al. 5418 (MBML, RB, UPCB); 9.IV.2009, fr., L. Kollmann et al. 11511 (MBML, RB, UPCB).

Material adicional examinado: BRASIL. ESPÍRITO SANTO: Santa Teresa, Museu de Biologia Prof. Mello Leitão, 21.XI.1998, fl., E. Bausen (MBML 5326).

Tibouchina arborea ocorre nos estados de MG, ES, SP, RJ. No PEFG ocorre em Floresta Ombrófila Densa Alto-montana. Distingue-se pelas flores com pétalas de coloração mutável e pelos estames com conectivos densamente revestidos por tricomas glandulares. As flores quando jovens possuem pétalas alvo lilases de base branca, mudando gradativamente para brancas com a base vermelha.

32. Tibouchina castellensis Brade, Arch. Jard. Bot. Rio de Janeiro 14: 215. 1956.

Fig. 3t-u

Arbusto 1-2 m alt.; ramos cilíndricos, ambas as faces das folhas e hipanto revestidos por tricomas dendríticos prostrados, com ramificações curtas. Folhas com pecíolo 0,4-1,4 cm compr.; lâmina 2,1-7 $\times 1-3,5 \mathrm{~cm}$, oblonga, base arredondada, margem inteira, ápice arredondado, às vezes mucronado, nervuras 5+2, basais. Panícula 3-13,5 cm compr., terminal. Flores 5-meras; hipanto 3,6-5,5 mm compr., urceolado; cálice simples, caduco; lacínias triangulares a triangular-alongadas; pétalas lilásclaro, não mutáveis, obovadas, ápice retuso; estames
10 , levemente dimórficos à isomórficos, filetes glabros a esparsamente revestidos por tricomas glandulares, conectivo prolongado $0,6-1,6 \mathrm{~mm}$ abaixo das tecas, apêndices ventrais, bilobados, anteras 5-8,2 mm compr., lilases a roxas, subuladas, ápice arredondado, poro apical único; ovário $2 / 3$ súpero, densamente revestido no ápice por tricomas simples, 5-locular; estilete 1,2-1,6 cm compr., curvo, glabro. Cápsula; sementes numerosas, cocleadas. Material examinado: Forno Grande, Pico, 12.VIII.1948, fl., A.C. Brade 19262 (RB); 9.IV.2004, f1., L. Kollmann 6615 (MBML, UPCB); 25.III.2005, fl., L. Kollmann 7571 et al. (MBML, UPCB); Mirante, 7.IV.2009, fl. e fr., J. Meirelles et al. 291 (UPCB*); trilha para as Piscinas, 12.II.2008, fl., L. Kollmann et al. 10550 (UPCB); trilha das Piscinas para o Mirante, 2.V.2008, fr., R. Goldenberg et al. 1071 (UPCB); trilha para a Goela da Onça, 19.VII.2008, fr., P. Labiak et al. 4852 (UPCB); Forninho, 20.V.2010, fl., J. Meirelles et al.464 (MBML, RB).

Tibouchina castellensis é endêmica do ES. No PEFG ocorre formando grandes populações restritas aos afloramentos rochosos inseridos em Floresta Ombrófila Densa Montana e Alto-montana. Caracteriza-se pelo hipanto urceolado e pelas pétalas de coloração não mutável, lilás-claro. É citada como Criticamente em Perigo na lista de espécies ameaçadas de extinção do Estado do Espírito Santo (Simonelli \& Fraga 2007).

33. Tibouchina cerastifolia (Naudin) Cogn., Fl. bras. 14 (3): 403. $1885 . \quad$ Fig. 4a-c

Erva terrícola ca. $0,4 \mathrm{~m}$ alt a subarbusto $2 \mathrm{~m}$ alt.; ramos cilíndricos a sub-cilíndricos, moderadamente revestidos por tricomas simples e por tricomas glandulares esparsos. Folhas com pecíolo 0,1-1,8 cm compr.; lâmina 1-6,4×0,4-2,4 cm, oval oblonga, base arredondada, margem serrilhada, ápice acuminado a agudo, ambas as faces moderadamente revestidas por tricomas simples, adpressos na face adaxial, face abaxial esparsamente revestida por tricomas glandulares, nervuras $3+2$ a $5+2$, basais, primeiro par central confluindo com o segundo, acima da base. Dicásio paniculado 12-54 cm compr., terminal, com ramos adicionais. Flores 4-5-meras; hipanto 3,8-5,2 mm compr., campanulado, moderadamente revestido por tricomas simples e esparsamente por tricomas glandulares; cálice simples, persistente; lacínias longo-triangulares; pétalas lilases não mutáveis, obovadas a lanceoladas, ápice acuminado a arredondado; estames 8-10, dimórficos, filetes glabros, conectivo dos estames menores prolongados 0,5-1,2 $\mathrm{mm}$ abaixo das tecas, dos estames maiores prolongado $0,8-1,4 \mathrm{~mm}$ abaixo das tecas, apêndices 

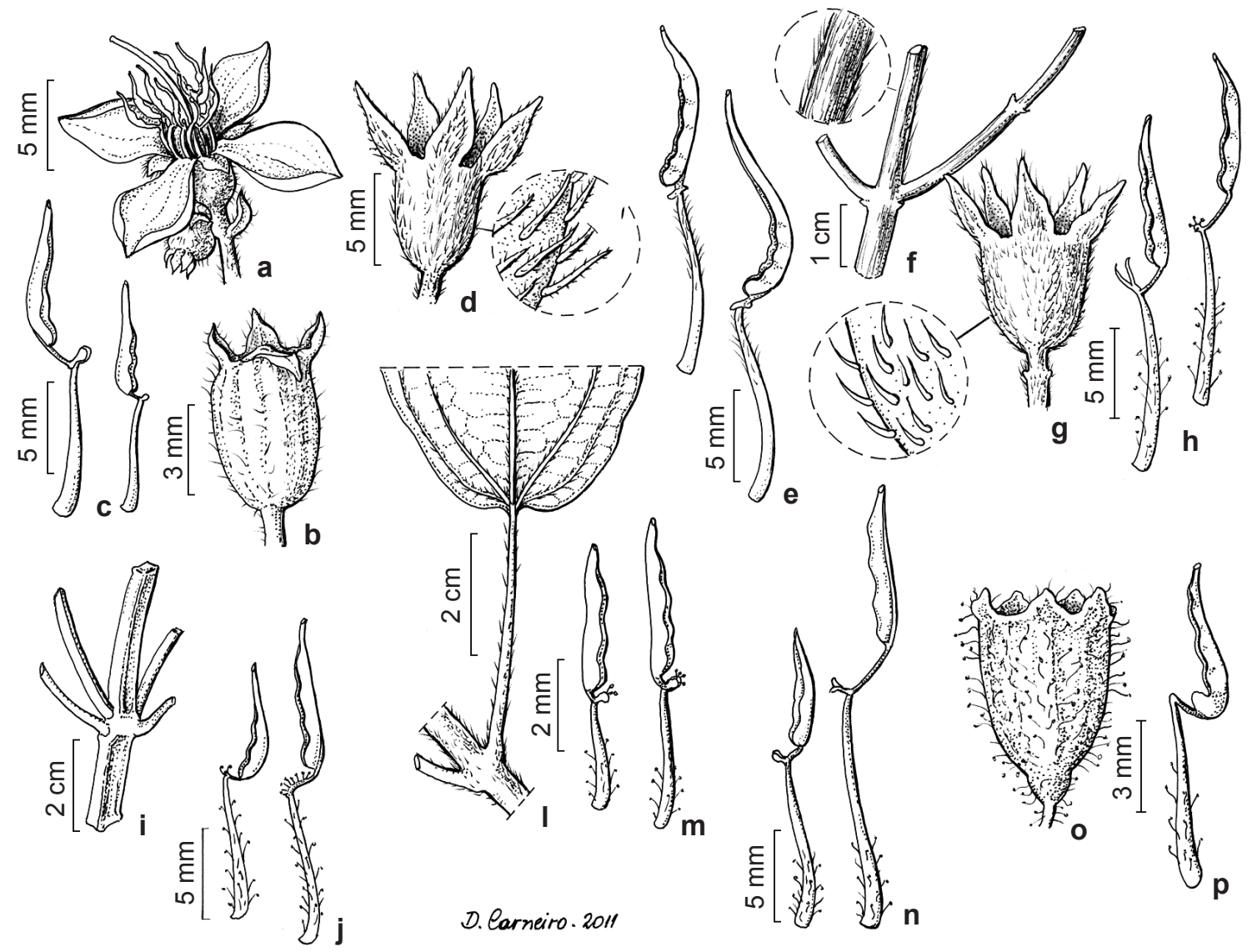

D. Carneiro. 2011
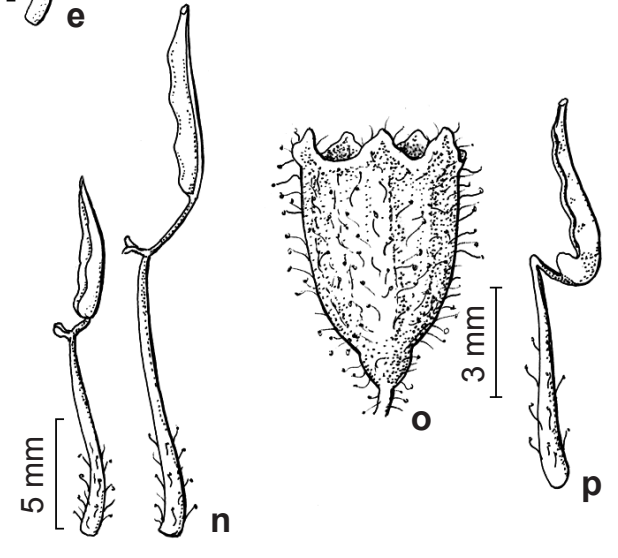

Figura 4 - a-c. Tibouchina cerastifolia - a. flor; b. fruto; c. estames (Meirelles et al. 450). d-e. T. estrellensis - d. hipanto com lacínias e detalhe de indumento (Meirelles et al. 283); e. estames (Meirelles et al. 302). f-h. T. fothergillae - f. ramo com detalhe de indumento; g. hipanto com detalhe de indumento (Meirelles et al. 462); h. estames (Meirelles et al. 465). i-j. T. heteromalla - i. ramo; j. estames (Meirelles et al. 287). 1-m. T. radula - 1. pecíolo e base da folha (Goldenberg et al. 1284); m. estames (Meirelles et al. 463). n. T. semidecandra-estames (Meirelles et al. 468). o-p. Tibouchina tedescoi - o. hipanto; p. estame (Goldenberg et al. 1290).

Figure 4 - a-c. Tibouchina cerastifolia - a. flower; b. fruit; c. stamens (Meirelles et al. 450). d-e. T. estrellensis - d. hypanthium with calyx lobes and detail of indument (Meirelles et al. 283); e. stamens (Meirelles et al. 302). f-h. T. fothergillae - f. branch with detail of indument; g. hypanthium with detail of indument (Meirelles et al. 462); $\mathrm{h}$. stamens (Meirelles et al. 465). i-j. T. heteromalla $-\mathrm{i}$. branch; j. stamens (Meirelles et al. 287). 1-m. T. radula - 1. petiole and base of the leaf (Goldenberg et al. 1284); m. stamens (Meirelles et al. 463). n. T. semidecandra - stamens (Meirelles et al. 468). o-p. Tibouchina tedescoi-o. hypanthium; p. stamen (Goldenberg et al. 1290).

ventrais, nos estames menores e maiores bituberculados, anteras menores 3,4-4,6 mm compr., maiores 3,8-6 mm compr., menores amarelas, maiores avermelhadas, subuladas, ápice arredondado, poro apical único; ovário $1 / 2 \mathrm{a} 2 / 3$ súpero, densamente revestido por tricomas simples, 4-locular; estilete 0,8-1,3 cm compr., linear a levemente curvo no ápice, glabro. Cápsula; sementes numerosas, cocleadas.

Material examinado: brejo próximo à sede do Parque, 1.V.2008, fl. e fr., R. Goldenberg et al. 1035 (RB, UPCB); trilha do rio Manso, 20.VII.2008, fl., fl. e fr., $R$. Goldenberg et al. 1197 (MBML, RB, UPCB); entre as
Piscinas e o Mirante, 7.IV.2009, fl., J. Meirelles et al. 286 (UPCB*); rio Manso, 19.V.2010, fl., fl. e fr., J. Meirelles et al. 450 (UPCB*).

Tibouchina cerastifolia ocorre nos estados do TO, MS, MG, SP, RJ, PR, SC, RS. No PEFG ocorre formando grandes populações em áreas abertas e em bordas de Floresta Ombrófila Densa Montana. Caracteriza-se principalmente pelo hábito herbáceo a subarbustivo e pelo cálice persistente. Possui flores 4-meras, raro 5-meras. Distingue-se também pela coloração das anteras, sendo as menores amarelas e as maiores amarelo-avermelhadas. 
34. Tibouchina estrellensis (Raddi) Cogn., Fl. bras. 14(3): 342. 1885.

Fig. $4 d-e$

Arvoreta a árvore 3-17 m alt.; ramos quadrangulares, densamente revestidos por tricomas dendríticos. Folhas com pecíolo 0,5-2 cm compr.; lâmina 3-13,3 × 1,2-4,3 cm, oval-oblonga, base arredondada, margem inteira, ápice arredondado, levemente acuminado, face adaxial moderadamente revestida por tricomas simples encurvados com base bulada e estrias claras, face abaxial densamente revestida por tricomas dendríticos, nervuras $5+2$, basais, segundo par confluente ao primeiro par central. Panícula 5-15 cm compr., terminal. Flores 5-meras; hipanto ca 5,8 $\mathrm{mm}$ compr., oblongo, densamente revestido por tricomas dendríticos; cálice simples, caduco; lacínias externamente longo-triangulares, internamente ovais; pétalas roxas, não mutáveis, obovadas, ápice truncado; estames 10, dimórficos, filetes com metade apical do comprimento densamente revestido por tricomas simples, conectivo dos estames menores prolongado 0,5-1 mm abaixo das tecas, dos estames maiores prolongado $0,9-1,3 \mathrm{~mm}$ abaixo das tecas, apêndices ventrais, bi-tuberculados, anteras menores $0,7-1$ cm compr., maiores $0,8-1,2 \mathrm{~cm}$ compr., roxas, subuladas, ápice arredondado, poro apical único; ovário $2 / 3$ súpero, densamente revestido por tricomas simples, 5-locular; estilete 1,6-2 cm compr., curvo, $2 / 3$ do comprimento densamente revestidos por tricomas simples. Cápsula; sementes numerosas, cocleadas alongadas.

Material examinado: trilha para as Piscinas, 7.IV.2009, fl., J. Meirelles et al. 283 (UPCB*); entorno do alojamento, 9.VII.2009, fl., A. Amorim et al. 7802 (UPCB*); arredores do rio Manso, 19.V.2010, fr., J. Meirelles et al. 455 (MBML, RB); trilha da Balança, 21.V.2010, fr., J. Meirelles et al. 482 (UPCB*).

Tibouchina estrellensis ocorre nos estados de MG, ES, SP, RJ. No PEFG ocorre em populações de poucos indivíduos em Floresta Ombrófila Densa Montana e Alto-montana. Distingue-se pelo hipanto revestido por tricomas dendríticos e pelos filetes com tricomas simples.

35. Tibouchina fothergillae (DC.) Cogn., Fl. bras. 14(3): 320. 1885.

Fig. 4f-h

Arbusto a arvoreta 1-5 m alt.; ramos cilíndricos, densamente revestidos por tricomas simples. Folhas com pecíolo 0,2-1,5 cm compr.; lâmina 1,1-6,7 × $0,5-2,3 \mathrm{~cm}$, oval-oblonga a lanceolada, base aguda a arredondada, margem inteira, ápice acuminado, face adaxial moderadamente revestida por tricomas simples, ásperos e rígidos, face abaxial densamente revestida por tricomas simples, nervuras 5, basais, segundo par confluente ao primeiro par central. Flores solitárias ou em dicásio, terminais. Flores 5-6-meras; hipanto 3,8-5,1 mm compr., campanulado, densamente revestido por tricomas simples de base alargada; cálice simples, caduco; lacínias largamente triangulares com ápice subulado; pétalas roxas, não mutáveis, obovadas, ápice truncado a retuso; estames 10 , dimórficos, filetes revestidos por tricomas glandulares, conectivo nos estames menores prolongado $1-2,4 \mathrm{~mm}$ compr. abaixo das tecas, nos maiores prolongado $(0,9) 1-9 \mathrm{~mm}$ abaixo das tecas, apêndices ventrais, nos estames menores bífidos, nos maiores bilobados moderadamente revestidos por tricomas glandulares, anteras dos estames menores 4,1-5,9 $\mathrm{mm}$ compr., dos maiores 5,2-7,5 $\mathrm{mm}$ compr., lilases, subuladas, ápice arredondado, poro apical único; ovário $1 / 2 \mathrm{a} 2 / 3$ súpero, densamente revestido por tricomas simples, e eretos, 5-locular; estilete 5-7,2 mm compr., linear a curvo, moderadamente a esparsamente revestido por tricomas simples. Cápsula; sementes numerosas, cocleadas.

Material examinado: 9.IV.2004, fl., fl. e fr., L. Kollmann \& R.L. Kollmann 6632 (MBML, UPCB); 10.VI.2004, fl., L. Kollmann \& R.L. Kollmann 6698 (MBML, UPCB); 25.III.2005, fl., L. Kollmann et al. 7573 (MBML, UPCB); 25.III.2005, fl., L. Kollmann et al. 7574 (MBML, UPCB); mata próxima ao Mirante, inselbergue, 2.V.2008, fl., $R$. Goldenberg et al. 1053 (RB, UPCB); 16.VII.2008, fl. e fr., L. Kollmann \& A.P. Fontana 11093 (UPCB); Balança, 18.VII.2008, fr., C.N. Fraga et al. 2126 (RB, MBML, UPCB); trilha para as Piscinas, 17.VII.2008, fl., A.P. Fontana et al. 5394 (MBML, RB, UPCB); 7.IV.2009, fl., J. Meirelles et al. 290 (UPCB*); trilha do Forninho, 20.V.2010, fl., fl. e fr., J. Meirelles et al. 462 (MBML, RB, UPCB); afloramento por baixo do Mirante, 22.V. 2010, fl., J. Meirelles et al. 490 (MBML, RB, UPCB).

Tibouchina fothergillae ocorre nos estados de MG, ES, SP, RJ. No PEFG é comum e ocorre em populações pequenas associada a ambientes úmidos com afloramentos rochosos em Floresta Ombrófila Densa Montana e Alto-montana. Distingue-se pelo porte predominantemente arbustivo com copas largas e pelas flores solitárias ou em dicásios 5meras, mas ocasionalmente 6-meras.

36. Tibouchina heteromalla (Don) Cogn., Fl. bras . 14(3): 336. 1906.

Fig. 4i-j

Arbusto 1-2,5 m alt.; ramos quadrangulares, densamente revestidos por tricomas simples de base alargada, adpressos. Folhas com pecíolo 0,3-2,5 cm compr.; lâmina $1-12 \times 0,6-7 \mathrm{~cm}$, 
oval a oval-oblonga, base arredondada levemente cordada, raramente atenuada, margem inteira, ápice cuneado, arredondado, raramente acuminado, face adaxial bulada, densamente revestida por tricomas dendríticos sobre as bulas, e com tricomas simples ao redor, face abaxial revestida por tricomas simples de base alargada prostrados sobre as nervuras, tricomas delgados e enovelados no restante da seperfície da folha, nervuras $3+2$, basais. Panícula 4,5-38 cm compr., terminal. Flores 5-meras; hipanto 5-6 mm compr., oblongo, raramente campanulado, densamente revestido por tricomas simples de base alargada, adpressos; cálice simples, caduco; lacínias longo-triangulares; pétalas roxas, não mutáveis, obovadas, ápice arredondado, levemente truncado; estames 10, dimórficos, filetes revestidos por tricomas glandulares, conectivo dos estames menores prolongado 0,6-1,7 mm abaixo das tecas e dos maiores prolongado $0,7-2 \mathrm{~mm}$, apêndices ventrais, levemente bilobados, revestidos moderadamente por tricomas glandulares, anteras 2-5 $\mathrm{mm}$ compr. nos estames menores, brancas, e 4,1-5,4 mm compr. nos maiores, lilases, subuladas, ápice arredondado, poro apical único; ovário $1 / 2$ a $2 / 3$ súpero, densamente revestido por tricomas simples eretos, 5-locular; estilete 5,6-7,6 mm compr., curvo, $1 / 2$ do comprimento densamente revestido por tricomas simples, adpressos. Cápsula; sementes numerosas, cocleadas.

Material examinado: 25.III.2005, fl., L. Kollmann et al. 7572 (RB, MBML); trilha para as Piscinas, 12.II.2008, fl., L. Kollmann et al. 10549 (MBML); inselbergue próximo a sede do Parque, 1.V.2008, fl., R. Goldenberg et al. 1043 (RB, UPCB); entre as Piscinas e o Mirante, 7.IV.2009, fl., fl. e fr., J. Meirelles et al. 287 (UPCB*); Forninho, 20.V.2010, fl., J. Meirelles et al. 465 (UPCB*); 20.V.2010, fr., J. Meirelles et al. 475 (MBML, RB); trilha da Balança, 21.V.2010, fr., J. Meirelles et al. 483 (MBML, RB);

Tibouchina heteromalla ocorre nos estados da PB, PE, GO, MG, ES, SP, RJ. No PEFG ocorre formando grandes populações às margens de Floresta Ombrófila Densa Montana e Alto-montana e em inselbergues. Distingue-se das demais espécies pelos ramos pronunciadamente quadrangulares, canaliculados e pelas folhas grandes, densamente revestidas por tricomas macios.

37. Tibouchina radula Markgr., Notizbl. Bot. Gart. Berlin-Dahlem 10: 49. $1927 . \quad$ Fig. 41-m

Arbusto 0,8-1,5 m alt.; ramos cilíndricos a quadrangulares arredondados, revestidos por tricomas simples de base alargada, adpressos. Folhas com pecíolo 0,7-5,3 cm compr.; lâmina 2-12,7 × $1,5-7,7 \mathrm{~cm}$, oval, base obtusa a cordada, margem inteira, ápice arredondado a cuneado, face adaxial revestida por tricomas simples encurvados com base bulada, face abaxial densamente revestida por tricomas simples, mais espessos sobre as nervuras e com base alargada, nervuras $5+2$, basais. Panícula 0,3-1 m compr., terminal. Flores 5-meras; hipanto 4,4-4,8 mm compr., campanulado, moderadamente revestido por tricomas simples de base alargada, adpressos; cálice simples, caduco; lacínias longotriangulares; pétalas roxas, não mutáveis, obovadas, ápice truncado a retuso; estames 10, dimórficos, filetes com $1 / 2$ do comprimento moderadamente revestido por tricomas glandulares, conectivo dos estames menores prolongado $0,3-0,5 \mathrm{~mm}$ abaixo das tecas, dos estames maiores prolongado 0,7-1 mm abaixo das tecas, apêndices ventrais, moderadamente revestidos por tricomas glandulares, anteras menores 2,4-3,7 mm compr., maiores 3,1-4,1 mm compr., ambas brancas, subuladas, ápice arredondado, poro apical único; ovário $2 / 3$ súpero, densamente revestido por tricomas simples, 5-locular; estilete 4,8-5,2 mm compr., curvo, $2 / 3$ do seu compr. moderadamente revestido por tricomas simples. Cápsula; sementes numerosas, cocleadas. Material examinado: afloramento por baixo do Mirante, 16.VII.2008, fl., L. Kollmann \& A.P. Fontana 11082 (RB, UPCB); trilha para o Forninho, 21.I.2009, fl. e fr., R. Goldenberg et al. 1281 (MBML, RB, UPCB); inselberg por baixo do Mirante, 9.IV.2009, fl. e fr., $J$. Meirelles et al. 298 (UPCB*); Forninho, 20.V.2010, fl., fl. e fr., J. Meirelles et al. 463 (MBML); fr., J. Meirelles et al. 474 (MBML).

Tibouchina radula ocorre nos estados da $\mathrm{PB}$ e ES. No PEFG ocorre representada por poucos indivíduos restritos aos afloramentos rochosos inseridos em Floresta Ombrófila Densa Montana e Alto-montana. Distingue-se das demais espécies pelas inflorescências longo pedunculadas que chegam a medir $1 \mathrm{~m}$ compr. e pelas folhas coriáceas com a superfície adaxial muito áspera ao tato.

38. Tibouchina semidecandra Cogn., Fl. bras. 14(3): 309. 1885.

Fig. 4n

Arbusto 1,5-2 m alt.; ramos cilíndricos, densamente revestidos por tricomas simples de base alargada, as partes mais velhas glabras. Folhas com pecíolo $0,2-0,8 \mathrm{~cm}$ compr.; lâmina $1,1-5 \times 0,7-2,4 \mathrm{~cm}$, oval, oblonga ou lanceolada, base arredondada a atenuada, margem serreada, ápice cuneado, arredondado ou acuminado, face adaxial revestida por tricomas simples com base bulada e ápice encurvado, face abaxial densamente revestida por tricomas simples, encurvados, 
nervuras $3+2$, basais. Flores solitárias, terminais, 5-meras; hipanto 10-15 mm compr., campanulado, densamente revestido por tricomas simples, rígidos e adpressos; cálice simples, caduco; lacínias oblongas, ápice arredondado; pétalas roxas, não mutáveis, obovadas, ápice truncado arredondado; estames 10, dimórficos, filetes esparsamente revestidos por tricomas simples e glandulares, conectivo dos estames menores prolongado 1,2$1,7 \mathrm{~mm}$ abaixo das tecas e dos estames maiores prolongado 6,3-7 $\mathrm{mm}$ abaixo das tecas, apêndices ventrais, bi-auriculados nos menores e bífidos nos maiores, anteras dos estames menores 0,9-1 cm compr., bege, dos maiores 1,2-1,4 cm compr., roxas, subuladas, ápice arredondado, poro apical único; ovário $1 / 2$ súpero, densamente revestido por tricomas simples, 5-locular; estilete 1,5 cm compr., linear, levemente curvo no ápice, glabro. Cápsula; sementes numerosas, cocleadas.

Material examinado: 30.X.2004, fl. e fr., L. Kollmann et al.7170 (MBML, UPCB); Forninho, 21.I.2009, fr., $R$. Goldenberg et al. 1288 (UPCB*); mata do Forninho, 20.V.2010, fl. e fr., J. Meirelles et al. 468 (MBML, UPCB).

Tibouchina semidecandra ocorre nos estados de $\mathrm{MG}, \mathrm{SP}, \mathrm{RJ}, \mathrm{ES}$ (primeiro registro). No PEFG é representada por poucos indivíduos que ocorrem em apenas uma localidade situada em Floresta Ombrófila Densa Alto-montana. Distingue-se das demais espécies pelas brácteas involucrais e pelos conectivos dos estames maiores com apêndices pronunciadamente bífidos.

39. Tibouchina tedescoi Meirelles, L. Kollmann \& R. Goldenb. Kew Bull. 67 (3): 461-465. 2012.

Fig. 4o-p

Arbusto 1-1,5 m alt.; ramos quadrangulares arredondados, densamente revestidos por tricomas simples, prostrados. Folhas com pecíolo 0,5-2,4 cm compr.; lâmina 1,8-8,7 × 1,3-6 cm, ovalarredondada a cordada, base arredondada, obtusa ou cordada, margem inteira, ápice cuneado, face adaxial bulada, densamente revestida por tricomas simples, prostrados, face abaxial densamente revestida por tricomas simples, encurvados, aqueles sobre a nervura central com a base pronunciadamente alargada, tricomas internos às fóveas mais delgados e enovelados, nervuras $3+2$, basais. Panícula 7,5$9,4 \mathrm{~cm}$ compr., terminal. Flores 5-meras; hipanto 6,2-8,5 mm compr., campanulado, densamente revestido por tricomas glandulares; cálice simples, caduco; lacínias oblongas com ápice acuminado; pétalas roxas não mutáveis, obovadas, ápice truncado; estames 10, isomórficos a levemente dimórficos, filetes revestidos na região inferior por tricomas glandulares, conectivo prolongado 0,6-0,9 mm abaixo das tecas, apêndices ventrais, formados por duas projeções agudas nos levemente maiores e bi-tuberculados nos menores, anteras 3,7-4,5 mm compr., lilases claras, subuladas, ápice arredondado, poro apical único; ovário $1 / 2$ súpero, densamente revestido por tricomas simples eretos e rígidos, lóculos não visualizados; estilete ca. 7 mm compr., linear, levemente curvado no ápice, revestido por tricomas glandulares até $1 / 3$ do seu compr. Fruto cápsula; sementes não vistas.

Material examinado: subida para o Fornão, 1.XI.2004, fr., A.P. Fontana et. al. 1002 (MBML, UPCB); Forninho, 21.I.2009, fl., R. Goldenberg et al. 1290 (RB).

Tibouchina sp. nov. é potencialmente endêmica do ES. No PEFG forma uma pequena população restrita a afloramentos rochosos inseridos em Floresta Ombrófila Alto-montana. Caracterizase pelo hipanto densamente revestido por tricomas glandulares. Alguns exemplares haviam sido determinados anteriormente como T. heteromalla, espécie da qual difere pelas inflorescências e ramos da inflorescência consideravelmente menores, pela ausência de glândulas no conectivo dos estames e indumento da superfície adaxial das folhas.

\section{Agradecimentos}

Os autores agradecem a CAPES a bolsa de mestrado concedida a primeira autora, ao CNPQ a bolsa de produtividade concedida ao segundo autor; ao IEMA a licença de coleta no PEFG, a Fundação O Boticário e Fundação Araucária o financiamento das excursões em campo; aos curadores dos herbários MBML, RB e UPCB por terem possibilitado a análise de seu acervo e o empréstimo de material; a Ludovic Kollmann e à equipe do projeto "Diversidade da flora vascular e status de conservação das espécies endêmicas em três Unidades de Conservação no Estado do Espírito Santo" as coletas na área do Parque e auxílio em campo; ao seu Alair Tedesco e Jovani Pereira o auxílio em campo; e a Diana Carneiro as ilustrações.

\section{Referências}

Backes, P. \& Irgang, B. 2004. Mata atlântica, as árvores e a paisagem. Paisagem do Sul, Porto Alegre. 396p.

Baumgratz, J.F.A.; Bernardo, K.F.R.; Chiavegatto, B.; Goldenberg, R.; Guimarães, P.J.F.; Kriebel, R.; Martins, A.B.; Michelangeli, F.A.; Reginato, M.; Romero, R.; Souza, M.L.D.R. \& Woodgyer, E. 2010a. Melastomataceae. In: Lista de espécies da flora do Brasil. Jardim Botânico do Rio de Janeiro. 
Disponível em <www.floradobrasil.jbrj.gov.br/2010/ FB000161>. Acesso em 18 Mar 2010.

Baumgratz, J.F.A.; Souza, M.L.D.R. \& Tavares, R.A.M. 2010b. Melastomataceae de Macaé de Cima. Disponível em <www.jbrj.gov.br/pesquisa/pma/ macaedecima/checklist/Lista_Plantas_Vasculares. htm>. Acesso 18 Mar 2010.

Brade, A.C. 1959. Melastomataceae Novae VI. Arquivos do Jardim Botânico do Rio de Janeiro 26: 6-26.

Clausing, G. \& Renner, S.S. 2001. Molecular phylogenetics of Melastomataceae and Memecylaceae: implications for character evolution. American Journal of Botany 88: 486-498.

Cogniaux, A.C. 1891. Melastomaceae. In: De Candolle, A. \& De Candolle, C. (eds.). Monographiae Phanerogamarum. G. Masson, Paris. Vol. 7. Pp. 1-1256.

Conservation International do Brasil, 2000. Avaliação e ações prioritárias para a conservação da biodiversidade da Mata Atlântica e Campos Sulinos. Ministério do Meio Ambiente/Secretaria de Biodiversidade e Florestas, Brasília. 40p.

Goldenberg, R. 2004. O gênero Miconia (Melastomataceae) no estado do Paraná, Brasil. Acta Botanica Brasilica 18: 927-947.

Goldenberg, R. \& Reginato, M. 2006. Sinopse da família Melastomataceae na Estação Biológica de Santa Lúcia, Santa Teresa, Espírito Santo. Boletim do Museu de Biologia Mello Leitão 19: 31-56.

Goldenberg, R. \& Tavares, R.A.M. 2007. A new species of Dolichoura (Melastomataceae) and broadened circumscription of the genus. Brittonia 59: 226-232.

IPEMA. 2005. Conservação da Mata Atlântica no estado do Espírito Santo: Cobertura florestal e unidades de conservação. IPEMA, Vitória. 142p.

Jardim, A.Q.B.S. 2009. Melastomataceae de Floresta Montana na RPPN Serra das Lontras, Bahia, Brasil. Dissertação de Mestrado. Universidade Estadual de Feira de Santana, Feira de Santana. 69p.

Martins, A.B. 2009. Melastomataceae. In: Martins, S.E.; Wanderley, M.G.L.; Shepherd, G.J.; Giulietti, A.M. \& Melhem, T.S. (eds.). Flora fanerogâmica do estado de São Paulo. Instituto de Botânica, São Paulo. Vol. 6. Pp. 1-4.
Mendoza H. \& Ramires B. 2006. Guía ilustrada de géneros de Melastomataceae y Memecylaceae de Colombia. Instituto de Investigación de Recursos Biológicos Alexander von Humboldt, Bogotá. 280p.

Renner, S.S. 1993. Phylogeny and classification of the Melastomataceae and Memecylaceae. Nordic Journal of Botany 13: 519-540.

Romero, R. \& Martins, A.B. 2002. Melastomataceae do Parque Nacional da Serra da Canastra, Minas Gerais, Brasil. Revista Brasileira de Botânica 25: 19-24.

Semir, J.; Chiea, S. \& Martins, A.B. 1987. Melastomataceae. In: Giulietti, A.M.; Menezes, N.L.; Pirani, J.R.; Meguro, M. \& Wanderley, M.G.L. (orgs.). Flora da Serra do Cipó, Minas Gerais: caracterização e lista das espécies. Boletim de Botânica da Universidade de São Paulo 9: 72-78.

Simonelli, M. \& Fraga, C. N. 2007. Espécies da flora ameaçadas de extinção no estado do Espírito Santo. IPEMA, Vitória. 146p.

Thiers, B. 2010 [continuosly updated]. Index Herbariorum: a global directory of public herbaria and associated staff. New York Botanical Garden's Virtual Herbarium. Disponível em < www.sweetgum. nybg.org/ih>. Acesso em 18 Jan 2011.

Thomaz, L. D. \& Monteiro, R. 1997. Composição florística da Mata Atlântica de encosta da Estação Biológica de Santa Lúcia, município de Santa Teresa - Espírito Santo. Boletim do Museu de Biologia Mello Leitão. 7: 3-48.

Toledo, J.F. 1942. Guia do herborizador e preparador de fanerógamas. Instituto de Botânica, São Paulo. 43p.

Wurdack, J.J. 1962. Melastomataceae of Santa Catarina. Sellowia 14: 109-217.

Wurdack, J.J. 1973. Melastomataceae. In: Lasser, T. (ed.). Flora de Venezuela. Instituto Botánico, Caracas. Vol. 8. Pp. 1-819.

Wurdack, J.J. 1980. Melastomataceae. In: Harling, G. \& Sparre, B. (eds.). Flora of Ecuador. Vol. 13. University of Goteborg, Goteborg. Pp. 1-406.

Wurdack, J.J.; Renner, S.S. \& Morley, T. 1993. Melastomataceae. In: Van Rijn, A.R.A.G. (ed.). Flora of the Guianas. Vol. 99. Koeltz Scientific Books, Koenigstein. Pp. 1-425. 
